\title{
Originalism and the Unwritten Constitution
}

Lawrence B. Solum

Georgetown University Law Center, Ibs32@law.georgetown.edu

This paper can be downloaded free of charge from:

https://scholarship.law.georgetown.edu/facpub/1300

2013 U. III. L. Rev. 1935-1984 (2013)

This open-access article is brought to you by the Georgetown Law Library. Posted with permission of the author. Follow this and additional works at: https://scholarship.law.georgetown.edu/facpub

Part of the Constitutional Law Commons, Legal History Commons, and the Legal Theory Commons 


\title{
ORIGINALISM AND THE UNWRITTEN CONSTITUTION*
}

\author{
Lawrence B. Solum**
}

\begin{abstract}
In his book, America's Unwritten Constitution, Akhil Reed Amar contends that to properly engage the written Constitution, scholars and laymen alike must look to extratextual sources: among them America's founding documents, institutional practices, and ethos, all of which constitute Amar's "unwritten Constitution." In this Article, I argue that contemporary originalist constitutional theory is consistent with reliance on extraconstitutional sources in certain circumstances. I establish a framework for revaluating the use of extratextual sources. That framework categorizes extratextual sources and explains their relevance to constitutional interpretation (the meaning of the text) and constitutional construction (elaboration of constitutional doctrine and decision of constitutional cases). I conclude by applying the framework to a question posed by Akhil Amar: Can vice presidents preside over their own trial upon impeachment? A negative answer to this question is consistent with an originalist constitutional theory that carefully cabins the use of extratextual sources in constitutional interpretation and construction.
\end{abstract}

\section{INTRODUCTION: THE PROBLEM OF AN UNWRITTEN CONSTITUTION FOR ORIGINALISTS}

In 1975, Thomas Grey asked, "Do we have an unwritten constitution?" His question has been echoed by Michael Moore, ${ }^{2}$ Antonin Scalia, ${ }^{3}$ and others. ${ }^{4}$ Recently, Akhil Amar has provided his own distinctive

* (c) 2012 by the Author. Permission is hereby granted to make copies in tangible or electronic form, including but not limited to the distribution of this work in whole or in part for educational or scholarly purposes.

** John Carroll Research Professor of Law, Georgetown University Law Center.

1. Thomas C. Grey, Do We Have an Unwritten Constitution?, 27 STAN. L. REV. 703, 703 (1975).

2. Michael S. Moore, Do We Have an Unwritten Constitution?, 63 S. CAL. L. REV. 107, 107 (1989).

3. Antonin Scalia, Is There an Unwritten Constitution?, 12 HARV. J. L. \& PUB. POL'Y 1 (1989).

4. The literature on unwritten constitutions, unenumerated constitutional rights, the Ninth Amendment, and related topics is vast. Some of the work that influenced the writing of this Article in particular include: Jed Rubenfeld, The New Unwritten Constitution, 51 DuKE L.J. 289 (2001); Suzana Sherry, The Founders' Unwritten Constitution, 54 U. CHI. L. REV. 1127 (1987); Adrian Vermeule, The Facts About Unwritten Constitutionalism: A Response to Professor Rubenfeld, 51 DUKE L.J. 473 (2001). 
answer to Grey's question in America's Unwritten Constitution. ${ }^{5}$ One of the motivations for Grey's essay was the early stirrings of originalism; descendants of the interpretivism and textualism that Grey interrogated now occupy center stage in contemporary debates about constitutional theory. But since Grey wrote his essay, originalism and textualism have evolved. This Article addresses the idea of an unwritten constitution from the perspective of contemporary originalist theory. Is the notion of an unwritten constitution consistent with the originalist claim that constitutional practice should be constrained by the original public meaning of the constitutional text?

We can begin with a preliminary statement of the problem as the conjunction of three propositions: (1) The predominate form of contemporary originalism is textualist; let's call this form of originalism "public meaning originalism." (2) An unwritten constitution is not a text. (3) Therefore, public meaning originalists should reject the notion of an unwritten constitution.

This simple syllogism ${ }^{6}$ is misleading, in part because the phrase "unwritten Constitution" provides an unfortunate frame for the real issues at hand. The United States does not have an unwritten constitution in the same sense that the United Kingdom does - no one seriously disputes that claim (if it is understood narrowly). And even the United Kingdom has a constitution comprised largely of writings-although the writings are not an integrated document but are instead a collection of statutes, royal proclamations, and many other texts. Opponents of an unwritten constitution do not dispute the existence of judicial decisions that create or articulate rules of constitutional law. In some senses, we do have an unwritten constitution. In other senses, we do not. Framing the issues in terms of the notion of an "unwritten constitution" obscures rather than illuminates the questions that are at stake.

In this Article, we will use a substitute vocabulary. The phrase "extratextual sources" will be used to designate sources of constitutional law that are outside the complete text of the U.S. Constitution (as amended). One incomplete version is under glass in the national archives; complete versions with the amendments can be found in the U.S. Code and on the Internet. Extratextual sources include judicial opinions, the Articles of Confederation, the Declaration of Independence, the ethos of the Framing era, theories of justice, the Northwest Ordinance, and the historical practices of the institutions of government and the American peopleand many other things as well.

Here is the plan. In Part II, I will attempt to concisely formulate the core of originalism as a constitutional theory. Part III will address extraconstitutional sources, laying out a typology of the sources themselves

5. AkHil Reed Amar, America's Unwritten Constitution: The Precedents And PRICIPLES WE LIVE BY (2012).

6. The word "syllogism" is used loosely: as stated, the argument is enthymematic, although the true syllogistic version could easily be stated. 
and the roles that they can play in constitutional interpretation and construction. Part IV will then examine particular extratextual sources from an originalist perspective. Part V concludes.

\section{ORIGINALISM}

Our topic is the relationship between originalism and extratextual sources of constitutional law. We can begin by asking the question, "What is originalism?"

\section{A. Communicative Content and Legal Content}

Let me begin with a very general distinction in legal theory-the distinction between "legal content" and "communicative content." " As applied to the Constitution, this distinction marks the difference between the legal content of constitutional doctrine and norms, on the one hand, and the communicative content (linguistic meaning in context) of the constitutional text, on the other hand. This distinction is fundamental to our investigation of the relationship between originalism and extratextual sources of constitutional norms, and we need to be clear and precise about these foundational ideas before we proceed further.

Let's begin with the idea of "communicative content." The "communicative content" of a legal text is its "meaning." But the word "meaning," standing alone is ambiguous. When we ask the question "what does this clause of the Constitution mean?," we might be asking about the linguistic meaning of the words - but we also might be asking about the effect that provision will have, or about the content of the doctrines of constitutional law that implement the clause. "Communicative content" refers to what we can roughly call the "linguistic meaning" of the text in the context in which it was framed and ratified. This rough and ready notion of communicative content is good enough for many purposes, but we can be a bit more precise.

How does a legal text (e.g., the Constitution) communicate? One part of the answer to that question focuses on the semantic meaning of the words and phrases that make up the text. If we want to know the meaning of the Commerce Clause, we need to know the meaning of the words in each clause: for example, the Commerce Clause includes the words "regulate," "commerce," "among," "several," and "states." Words have conventional semantic meanings-meanings that are determined by patterns of usage that produce shared linguistic conventions.

But the meaning of a clause (or a sentence in ordinary English) is not determined by the meaning of the words alone. There are further conventions, regularities in usage that determine the way words combine to produce meanings. We sometimes call these regularities "rules" of

7. See Lawrence B. Solum, Communicative Content and Legal Content, 89 NOTRE DAME L. REV. (forthcoming 2013).

8. U.S. CONST. art. I, $\S 8$, cl. 3 . 
grammar and syntax, but the term "rule" is somewhat misleading because it suggests that the regularities must conform to a prescriptive rule. Failure to conform would then constitute a violation-what we sometimes call a "grammatical error." Syntax and grammar enable meaning because of regularities in usage. Communication can take advantage of those regularities in various ways (not just by strict adherence to a "rule") and the regularities are not necessarily fully captured by the idea of a rule-there may be clusters and variations that are comprehended by competent speakers of the language.

The principle of compositionality expresses the idea that part of the meaning of an utterance (e.g., a clause in the Constitution) is the product of the conventional semantic meaning of the words, and the regularities of syntax and grammar that combine them. ${ }^{9}$ The contribution made by conventional semantic meanings, syntax, and grammar to the full communicative content of an utterance can be called its "semantic content." Lawyers sometimes call the semantic content of a statute its "literal meaning." In theoretical linguistics and the philosophy of language, the terms "syntax" and "semantics" are used to refer to the investigation of this component of meaning.

But the semantic content of an utterance does not do all the work. The meaning of a sentence is not always its "literal meaning." Words are uttered (or authored) in a context. This sentence (in this paper) provides a trivial example of the contribution made by context to meaning. The sentence immediately prior to this one (beginning "This sentence...") uses the word "this" in two places ("this sentence" and "this paper"). The word "this" is an indexical. ${ }^{10}$ Indexicals have conventional semantic meanings. Competent speakers of English understand words like "this," "here," "now," and so forth. But they would not know what "this" is, or where "here" is, or when "now" is, unless they had information about the context in which these words were uttered. Or take the word "Senate" as that word is used in the U.S. Constitution. ${ }^{11}$ Acontextually, "Senate" might mean "an assembly of citizens" or "the building in which a legislative assembly meets" or "the deliberative body of a college or university faculty." But in context, the word "Senate" refers to a particular legislative body created by the Constitution itself - the Senate of the United States that is part of the U.S. Congress created by the Constitution of 1789.

These examples of the contribution that context makes to meaning may seem trivial. There is nothing complex or counterintuitive about the examples - they are easy cases! But the intuitively obvious nature of

9. Donald Davidson, Theories of Meaning And Learnable Languages (1965), $r e$ printed in INQUIRIES INTO TRUTH AND INTERPRETATION 3, 7-13 (2d ed. 2001); Richard E. Grandy, Understanding and the Principle of Compositionality, 4 PHIL. PERSP. 557, 560 (1990).

10. See David Braun, Indexicals, STAN. ENCYClOPEDIA OF PHIL. (Oct. 15, 2007), http://plato. stanford.edu/entries/indexicals/; see also John Perry, Indexicals and Demonstratives, in A COMPANION TO Philosophy of LANGUAge 586-612 (Bob Hale \& Crispin Wright eds. 1997).

11. U.S. CONST. art. I, $\$ 1$. 
these examples is what makes them so powerful. They show beyond doubt that the communicative content of an utterance cannot be reduced to its semantic content. When it comes to the contribution that context makes to meaning, the case of legal texts is complex. For example, the clauses of the U.S. Constitution are embedded in multiple layers of context. Take the Constitution of 1789 (as it existed before amendment). Each Clause is embedded in a surrounding Article, and the Articles are embedded in the whole Constitution, which has a Preamble. The Constitution was framed and then ratified in a particular historical context. Some portion of the total context was shared in that it was generally available to the Framers, ratifiers, and citizens during the period of ratification. Call this common source of meaning "the publicly available context of constitutional communication" (or "the publicly available context" for short). This publicly available context combines with the semantic meaning of the words and phrases to produce the "communicative content" of the constitutional text.

Philosophy of language and theoretical linguistics use the word "pragmatics" to designate the study of the effect of context on communicative content. ${ }^{12}$ The contribution that context makes to communicative content can be called "pragmatic enrichment," but for our purposes we can use the phrase "contextual enrichment" to refer to this idea.

We can illustrate the idea of communicative content with an example. Take the free speech provision of the First Amendment to the U.S. Constitution. The semantic content (or "literal meaning") is sparse: "Congress shall make no law ... abridging the freedom of speech." Pace Justice Black, the literal meaning of the clause is both vague and ambiguous. ${ }^{13}$ What is "freedom of speech"? What constitutes an "abridging" of freedom of speech? Context enriches this content in various ways. The clause itself contrasts speech with press, assembly, and petition. The First Amendment is structurally related to the original Constitution, which includes a scheme of limited and enumerated congressional powers, and the Ninth Amendment that forbids constructions of the Constitution that deny or disparage rights retained by the people on the basis that other rights (including the freedom of speech) are enumerated. ${ }^{14}$ And the First Amendment was ratified in a particular historical context some of which was shared by the members of Congress that proposed the Bill of Rights, state legislators who voted on ratification, and by "We the People," the citizenry of the United States. This publicly available con-

12. Kepa Korta \& John Perry, Pragmatics, Stan. EnCyClopedia OF PhiL. (2011), http://plato. stanford.edu/archives/win2012/entries/pragmatics/.

13. JefFrey D. Hockett, New Deal Justice: The Constitutional Jurisprudence of Hugo L. Black, Felix Frankfurter, AND RoBert H. JACKSON 3, 98-107 (1996); Justice Black and the Bill of Rights (CBS television broadcast Dec. 3, 1968), available at 9 Sw. U. L. REV. 937, 938 (1977) (quoting Justice Black as saying "Well, I'll read you the part of the first amendment that caused me to say there are absolutes in our Bill of Rights. . . Now, if a man were to say this to me out on the street, 'Congress shall make no law respecting an establishment of religion'-that's the first amendment-I would think: Amen, Congress should pass no law.").

14. U.S. CONST. amends. I, IX. 
text of constitutional communication may have enriched the meaning of the phrase "freedom of speech" - giving relatively more clarity and determinacy to a phrase that would be highly underdeterminate considered out of context. This enriched meaning is the communicative content of the Free Speech Clause.

Now consider the legal content that is associated with the Free Speech Clause. Free speech doctrine is substantially more complex and rich than the meaning conveyed by the text of the First Amendmenteven taking contextual enrichment into account. The legal content of free speech doctrine includes a variety of complex legal rules-governing a wide variety of particular topics, ranging from the regulation of billboards to campaign finance and child pornography on the Internet. ${ }^{15}$ Take billboard regulation as an example: the Supreme Court has articulated what it calls "the law of billboards" as a subset of free speech doctrine ${ }^{16}$ but it is clearly the case that the legal content of this body of rules is not contained in the communicative content of the Free Speech Clause. Obviously, the law of billboards is not in the semantic contentneither the word billboard nor a synonym appears in the text. Almost as obviously, the precise content of the law of billboards is not a logical implication of the semantic content. And when we add the contribution made by the publicly available context of constitutional utterance, it is also obvious that the law of billboards was not in the communicative content of the First Amendment: competent speakers of English who were aware of the publicly available context would not have reliably predicted the precise contours of the Supreme Court's billboard doctrine.

The general point is about the contribution that context makes to communicative content. So far, I have illustrated this point using judicially crafted constitutional doctrine, but the same phenomenon can occur in the political branches with constitutional constructions articulated explicitly (e.g., in opinion letters or preambles) or assumed implicitly in both individual actions and settled practices.

More generally, the content of constitutional doctrine is far richer (i.e., contains more information) than does the communicative content of the constitutional text. In theory, one might imagine a regime of "super strict construction" - in which the content of constitutional doctrine is required to have a one-to-one correspondence with the communicative content of the constitutional text. In reality, the enormous complexity of constitutional practice has produced a set of constitutional doctrines that far outruns the linguistic meaning of the constitutional text.

15. Citizens United v. Fed. Election Comm'n, 558 U.S. 310 (2010) (establishing constitutional doctrine governing campaign finance regulation); Ashcroft v. Free Speech Coalition, 535 U.S. 234 (2002) (establishing constitutional doctrine governing child pornography on the Internet); Metromedia, Inc. v. City of San Diego, 453 U.S. 490, 501 (1981) (establishing constitutional doctrine governing communication via billboards).

16. Metromedia, Inc., 453 U.S. at 501. 


\section{B. The Core of Originalism}

With the distinction between communicative content and legal content in place, we are now in a position to give a relatively precise statement of the core of originalist constitutional theory. We shall focus on the core, because originalism is itself multifarious and complex. Originalism has evolved, both as a mode of judicial practice and as an academic theory. During the course of that evolution, the originalist family of constitutional theories has included versions that emphasized the original intentions of the Framers, the original understandings of the ratifiers, and original public meaning. ${ }^{17}$ Despite these variations, the originalist family is united by agreement on two core principles, which we can call "the fixation thesis" and "the constraint principle."

The fixation thesis can be stated as follows:

The communicative content of the Constitution (the linguistic meaning in context) is fixed at the time each constitutional provision is framed and ratified.

The idea expressed by the fixation thesis is simple, but its full articulation has two distinct components. The first component is semantic:

The semantic content of constitutional meaning is fixed by linguistic practices at the time each constitutional provision is framed and ratified.

For example, the phrase "domestic violence" is used today to refer to spousal abuse, child abuse, and elder abuse within a family, but contemporary usage is not an accurate guide to the semantic meaning of the same phrase that appears in Article IV of the United States Constitution; as used in the late eighteenth century "domestic Violence" referred to riots, rebellions, and other forms of harmful physical force within the territory of a political unit-in context, within the boundaries of a state. ${ }^{18}$ The first aspect of the fixation thesis is important because meanings change over time; this is the well-known phenomenon of linguistic drift. ${ }^{19}$

The second aspect of the fixation thesis goes to contextual enrichment - the contribution of context to communicative content. The context of a particular utterance or writing is fixed in time. This contextual component can be stated as follows:

The publicly available context of constitutional communication is fixed at the time the text is framed and ratified.

17. Lawrence B. Solum, What Is Originalism? The Evolution of Contemporary Originalist Theory, in THE CHALLENGE OF ORIGINALISM: THEORIES OF CONSTITUTIONAL INTERPRETATION 12, 33 (Grant Huscroft \& Bradley W. Miller eds., 2011).

18. See Jack M. Balkin, Living Originalism 37 (2011); Lawrence B. Solum, Semantic Originalism 3 (Ill. Pub. L. and Legal Theory Res. Papers Series, No. 07-24, 2008), available at http:// papers.ssrn.com/abstract $=1120244$. For a clever and utterly implausible argument to the contrary, see Mark S. Stein, The Domestic Violence Clause in "New Originalist" Theory, 37 Hastings CONST. L.Q. 129, 133-35 (2009). Cf. Jay S. Bybee, Insuring Domestic Tranquility: Lopez, Federalization of Crime, and the Forgotten Role of the Domestic Violence Clause, 66 GEO. WASH. L. REV. 1 (1997).

19. See Sol Steinmetz, Semantic Antics: How And Why Words Change MeAning, at viixiii (2008). 
Before giving examples, we need to note an important clarification. The context is fixed at the time the text is framed and ratified, but it includes the entire publicly available context-and that context may itself be composed of events that predate ratification. The Constitution of 1789 was drafted in 1787 and obtained sufficient votes for ratification in 1788. Similarly, each amendment is proposed and ratified during a particular period of time. ${ }^{20}$ For this reason, the publicly available context of each provision of the Constitution is time bound. The public context is likely to focus on communications and events that are close in time to the drafting and promulgation of the text, but events in the distant past could be important parts of the context to the extent that framers, ratifiers, and citizens shared the belief they were relevant to the meaning of some constitutional provision. But future events cannot be part of the publicly available context of constitutional communication-not without time travel!

In sum, the fixation thesis expresses the idea that communicative content is fixed in time. The thesis results from two facts about meaning: (1) semantic content is fixed by linguistic practice at the time of utterance, and (2) the context of an utterance is time bound.

The fixation thesis is the first element of the core of contemporary originalism. The second element is the constraint principle. The idea of the constraint principle is simple and highly intuitive:

The communicative content of the constitutional text should constrain the content of constitutional doctrine.

Although it might be theoretically possible for an originalist to view originalism as a purely linguistic theory, in practice originalists are concerned with the relationship between original meaning and constitutional practice, including the content of constitutional doctrine. At a minimum, originalists believe that the original public meaning of the text should play some role in determining how courts should decide cases and how other officials and branches (e.g., the President and Congress) should act. The role that communicative content plays in determining legal content and effect can be called its "contribution." Many living constitutionalists would agree that the original meaning of the text (if ascertainable) should play some role in determining the content of contemporary constitutional doctrine-although they may believe that original meaning can be trumped or outweighed by other factors. Living constitutionalists of this sort can be seen as affirming a very weak form of originalism.

Theorists who describe themselves as originalists characteristically believe that the contribution of the text to doctrine should be more robust - the constraint principle is meant to express this core belief in an

20. The Twenty-Seventh Amendment to the Constitution is a special case; it was proposed by Congress on September 25, 1789, but ratification did not occur until May 7, 1992. See Certification of Amendment to the Constitution of the United States Relating to Compensation of Members of Congress, 57 Fed. Reg. 21,187, 21,187-88 (May 19, 1992). 
abstract way that leaves room for differences among the different members of the originalist family of theories.

Together the fixation thesis and the constraint principle express the core of contemporary originalist thought. These are the ideas on which almost all originalists agree. As the historical evolution of originalist thought demonstrates, there is another topic upon which originalists have disagreed. We can introduce this topic via a question: what determines original meaning? In this Article, I will focus on one answer to this question - the version of originalism that is sometimes called "original public meaning originalism" or "the new originalism."

\section{Public Meaning Originalism}

The history of originalism includes a set of variations on the theme of original meaning. Some originalists have emphasized the original intentions of the Framers, others the original understanding of the ratifiers, and others the original public meaning of the constitutional text. ${ }^{21}$ This Article will adopt original-public-meaning originalism as the model case of originalism for two reasons. First, public-meaning originalism is the dominant form of originalism in contemporary originalist scholarship. ${ }^{22}$ Second, for reasons that I have explored at length in other work, I believe that public-meaning originalism is the best candidate for the correct or true theory of constitutional meaning. ${ }^{23}$ In this Article, we shall simply stipulate that public-meaning originalism serves as a model case of contemporary originalist theory. ${ }^{24}$

What is public-meaning originalism? Like other originalist theories, public-meaning originalism affirms the fixation thesis and the constraint principle. What is distinctive about public-meaning originalism can be expressed as the "public meaning thesis":

The communicative content of the Constitution is fixed (1) by the conventional semantic meaning of the text as understood by competent speakers of American English and (2) by the contextual enrichment added by the publicly available context at the time each provision of the Constitution was framed and ratified.

Thus, the communicative content of the Constitution of 1789 is fixed by linguistic practice and the publicly available context of the founding era. Similarly, the communicative content of the Fourteenth Amendment is fixed by linguistic practice and context in 1866 through 1868 .

21. See Solum, supra note 17 , at 12,33 .

22. Id. at $22-33$.

23. See Solum, supra note 18, at 2,18-19; LAWRENCE B. SOLUM, We are all Originalists Now. in Robert W. Bennett \& LaWrence B. Solum, Constitutional Originalism : A Debate 1, 54-64 (2011).

24. The phrase "model case" expresses the idea that public meaning originalism provides a model or instance of originalism. Another version of originalism could have been selected for this purpose. 


\section{The Interpretation-Construction Distinction}

One more idea is required to complete our description of originalism. This idea can be called "the interpretation-construction distinction." ${ }^{25}$ This distinction marks the difference between two related activities within constitutional practice. The first activity is the discovery of the communicative content of a legal utterance; I will use the term "interpretation" to name this first activity. The second activity is the determination of the legal content and legal effect produced by a legal text; I will use the term "construction" to name this second and distinct activity. The interpretation-construction distinction is an old one in American legal theory, and it has been much discussed recently in constitutional theory, ${ }^{26}$ but the words "interpretation" and "construction" are also used in a broader sense to refer to both activities (discovering meaning and determining legal effect). Nothing hangs on the terminology, since we could describe the interpretation-construction distinction using other words. ${ }^{27}$

To understand the significance of the interpretation-construction distinction for constitutional theory, we need to grasp another, related distinction from the philosophy of language and theoretical linguisticsthe distinction between "vagueness" and "ambiguity." 28 When we communicate via language (written or oral), we use words and phrases that can be formed into complex expressions using the rules of syntax and grammar. Sometimes, the smallest meaningful unit of expression is a single word. Other times, whole phrases carry meanings that cannot be decomposed into the meaning of constituent words. But whatever the relevant unit of meaning might be, both words and phrases can be either vague or ambiguous.

In ordinary speech, the distinction between vagueness and ambiguity is not always observed. The two terms are sometimes used interchangeably, and when this is the case, they both mark a general lack of what we might call "determinacy" (or "clarity" or "certainty") of meaning. But the terms "vague" and "ambiguous" also have technical (or more precise) meanings, such that there is a real difference in their meaning.

In this technical sense, ambiguity refers to the multiplicity of sense: a term is ambiguous if it has more than one sense. A classic example is the word "cool." In one sense "cool" means "low temperature," as in, "The room was so cool we could see our breath." In another sense, "cool" means something like "hip" or "stylish," as in, "Miles Davis was so cool that every young trumpet player imitated him." And cool has

25. Lawrence B. Solum, Originalism and Constitutional Construction, FORDHAM L. REv. (forthcoming).

26. Id.

27. Lawrence B. Solum, The Interpretation-Construction Distinction, 27 CONST. COMMENT. 95, $96(2010)$

28. Id. at $96-97$. 
several other senses - referring to temperament or self-control, to certain colors, and a lack of enthusiasm (or the presence of skepticism or mild hostility).

The technical sense of vagueness refers to the existence of borderline cases: a term is vague if there are cases where the term might or might not apply. A classic example is the word "tall." In one sense, "tall" refers to height (of a person or other entity) that is higher (in some way or to some degree) than average. Abraham Lincoln was tall: at almost 6' 4 " he was a paradigm case of tall for his time. Napoleon was not tall, although at 5' 6 " he was of average height for his time (British propaganda depicted him as short). There are persons who are clearly tall and clearly not tall, then there are borderline cases: for example, in the United States in the twenty-first century, males who are 5'11" are neither clearly tall nor clearly not. Finally, a given word or phrase can be both vague and ambiguous. Cool is ambiguous, and in the temperature sense, it is also vague.

How does the distinction between ambiguity and vagueness relate to the interpretation construction distinction? Consider the case of ambiguity first. Many words and phrases have the property of semantic ambiguity. That is, when a word or phrase is considered acontextually, it can have more than one meaning. Consider the thought experiment of a message in a bottle. You are at the beach and you find a slip of paper that contains only the word "cool" or the phrase "domestic violence." You can guess at the meaning, but you won't know how the author was using the word, because you lack information about context. Consider the same words as they appear in messages that provide additional context: "Hey dude, this message in a bottle thing is totally cool." Or: "I am a victim of domestic violence. Please protect me from my father." The additional context -in these cases provided by the sentence in which the message appears - is sufficient to resolve the semantic ambiguity.

In the interpretation of legal texts in general (and constitutional interpretation in particular), ambiguity can usually be resolved by resort to the publicly available context of communication. In the context of constitutional law (as opposed to arguing about constitutional theory), the phrase "domestic violence" is unambiguous. We know that it refers to things like insurrections, riots, and rebellions-not spousal, child, or elder abuse within a family. We can restate this point more formally:

Characteristically, ambiguity in the semantic content of a constitutional text is liquidated by context and hence does not appear in the communicative content of the text.

Because "interpretation" in the technical sense in which we are using that word is just the activity that ascertains the communicative content of a text, it follows that ambiguity in semantic content can usually be resolved by interpretation (so long as the interpreter takes context into account). 
The qualifying word "characteristically" expresses the notion that there is no guarantee that semantic ambiguity can be resolved by context. For example, it might be the case that complete information about the publicly available context of constitutional communication would resolve the ambiguity, but the relevant evidence of that context is no longer available because of the passage of time. Another possibility is that the text is inherently ambiguous. This could occur because the drafters of a legal text were unable to compromise on some issue. In this situation, they might choose language that is deliberately ambiguous and hence cannot be liquidated by resort to context. We can call these special cases "irreducible ambiguity."

Now consider vagueness. Recall that if a word is vague, the semantic meaning of the word admits of borderline cases. Hart expressed a similar idea with his notion of "core" and "penumbra." 29 In the core of settled meaning, the applicability of the rule to a particular case is clear. In the penumbra, we have a borderline case-where the application of the rule is underdetermined by the legal materials that are its source. Outside the penumbra, the rule clearly does not apply. Related to the notion of vagueness is the idea of "open texture": the relationship between vagueness and open texture may be complicated, but for our purposes on this occasion we can treat open texture as a species of vagueness.

Of course, we have recognized that there is a distinction between communicative content and legal content. From the fact that the communicative content (linguistic meaning in context) of a constitutional provision is vague, it does not automatically follow that the legal content is also vague - a vague constitutional provision could have received an authoritative construction that eliminates the vagueness.

Vague texts characteristically require construction. Of course, there are a variety of ways in which construction can liquidate ambiguity. A vague text can be translated into a bright line rule. Or the vague text can give rise to a multifactor-balancing test, the application of which will resolve the borderline case. Or the law may give a judge or other official discretion to decide the case by an ad hoc, all-things-considered judgment. Each of these modes of construction is a method by which the vague legal text can be given determinate legal effect. The take-away point is:

Characteristically, vagueness in the communicative content of a constitutional text is resolved by a legal norm that enables determination of the legal content or legal effect of the text.

Because "construction" in the technical sense in which we are using that word is just the activity that ascertains the legal content and effect of a

29. See H. L. A. Hart, The ConcePt OF LAw 119-20 (1961); see also H. L. A. Hart, Positivism and the Separation of Law and Morals, 71 HARV. L. REV. 593, 606-15 (1958). 
text, it follows that vagueness in communicative content is usually resolved by construction - although there may be exceptions. ${ }^{30}$

\section{CONSTItutional TeXT AND EXTRATEXTUAL SOURCES}

We can now return to our problem: can originalists embrace a partially unwritten constitution? Because the phrase "unwritten Constitution" is unfortunate for our purposes, we can ask this question more clearly: can originalists embrace extratextual sources of the legal content of constitutional doctrine and practice? We can address this question in two steps. First, we need to say something about extratextual sourceswhat are they? Second, we need to investigate the role that extratextual sources can play in constitutional interpretation and construction. When we have taken those two steps, we will be in a position to give an abstract answer to our question about originalism and extratextual sources of constitutional doctrine and practice. After we state the abstract answer, we will turn to a more particularized inquiry.

\section{A. Typology: Sources of Constitutional Norms}

What are the sources of constitutional norms? That's a big question. To make it more manageable, we can begin by distinguishing between two kinds of sources, which we can call "textual sources" and "extratextual sources." We might think of the textual sources as divided into two categories. The first category consists of contiguous strings of constitutional text that are marked off as discrete units of constitutional meaning; we can call these text strings "clauses." The second category of textual sources has to do with the properties of the text that emerge from the ways in which individual clauses relate to one another. We can call these relationships between clauses "structural features of the constitutional text" or "structure" for short. ${ }^{31}$

The second kind of source comes from outside the constitutional text-extratextual sources. At this stage of our investigation, we want to suspend judgment about the legitimacy of these extratextual sources-we are merely listing the possible candidates for the role of plausible sources of constitutional norms. Again, we can categorize the possibilities. One category consists of foundational documents other than the Constitution of the United States; examples include the Declaration of Independence, the Treaty of Paris, and the Articles of Confederation. Another category consists of documents and records that relate to the Framing and ratification of the original Constitution and its amendments; examples include The Federalist Papers, Madison's notes of the Philadelphia Convention,

30. Here is one possible exception: There may be some cases in which contextual enrichment precisifies a vague word or phrase. That is, there may be cases in which the semantic content contributed by a term is vague, but the communicative content is not vague because the publicly available context adds precisification - reducing the zone of underdetermination.

31. See infra text accompanying note 64 . 
and the records of the ratifying conventions. A third category of possible sources consists of moral and political values. ${ }^{32}$ The fourth category is social norms and values - the content of these norms may correspond to true propositions of political morality, but this need not be the case. The fourth category refers to what is sometimes called "ethos" - the positive morality of a particular political culture. The fifth category is institutional practice. One particularly salient member of this category consists of judicial decisions and opinions - that is, "precedent." But the practices of nonjudicial actors could also serve as a source of constitutional norms; sometimes the term "historical practice" is used to describe a subset of this category. Finally, the logical space of extratextual sources includes the idea that constitutional law might simply be "made up" by some official; judges come to mind.

Our typology is summarized in Table 1, which appears immediately below:

32. This third category-moral and political values-raises certain worries about the use of the word "source," because some legal positivists may believe that moral facts cannot determine legal content. Let us set aside positivist worries about use of the word "source" to describe the role that political morality could play in determining the content of constitutional norms; if you wish, you can substitute "constitutional actors' beliefs about moral and political values." The third category is described in terms of the values themselves (or the officials' beliefs about them). 
TABLE 1: SOURCES OF CONSTITUTIONAL NORMS

\begin{tabular}{|l|l|}
\hline From the Constitutional Text (Textual Sources) \\
\hline Clauses & $\begin{array}{l}\text { Commerce Clause, the 11 } \\
\text { Amendment, the Privileges or } \\
\text { Immunities Clause. }\end{array}$ \\
\hline Structure & $\begin{array}{l}\text { The structure of the Constitution } \\
\text { or its parts, e.g., the relationship } \\
\text { between the grants of power in the } \\
\text { first three Articles. }\end{array}$ \\
\hline Outside the Constitution (Extratextual Sources) \\
\hline Other Foundational Documents & $\begin{array}{l}\text { The Treaty of Paris, the Declara- } \\
\text { tion of Independence, the Articles } \\
\text { of Confederation, State Constitu- } \\
\text { tions, "Superstatutes" }\end{array}$ \\
\hline $\begin{array}{l}\text { Documents and Records Relating } \\
\text { to the Framing and Ratification of } \\
\text { the Original Constitution or its } \\
\text { Amendments }\end{array}$ & $\begin{array}{l}\text { Madison's Notes, the Ratification } \\
\text { Debates, the Federalist Papers, } \\
\text { the Antifederalist Papers }\end{array}$ \\
\hline $\begin{array}{l}\text { Moral and Political Philosophy } \\
\text { (Values) }\end{array}$ & $\begin{array}{l}\text { Consequentialism, Deontology, } \\
\text { Virtue Ethics, Social Contract } \\
\text { Theory, Justice as Fairness, Popu- } \\
\text { lar Sovereignty Theory }\end{array}$ \\
\hline Social Norms and Values & $\begin{array}{l}\text { Systems of belief and associated } \\
\text { behavior, shared beliefs about mo- } \\
\text { rality and politics, popular beliefs } \\
\text { about the actual or ideal content } \\
\text { of constitutional norms }\end{array}$ \\
\hline Institutional Practice & $\begin{array}{l}\text { Judicial decisions, legislation and } \\
\text { statutes, rules, practices, and in- } \\
\text { formal norms of Congress and the } \\
\text { Executive branch, also the analog } \\
\text { of these at the state and local level }\end{array}$ \\
\hline $\begin{array}{l}\text { The discretionary decisions of of- } \\
\text { ficials, including judges and execu- } \\
\text { tive branch officials }\end{array}$ \\
\hline
\end{tabular}




\section{B. Three Roles for Extratextual Sources in Constitutional Interpretation and Construction}

Our typology provides a rough and ready categorization of the possible sources of constitutional norms. Our next step is to focus on the extratextual sources and investigate the roles they might play in the activities of constitutional interpretation and construction. Let's begin with the role that such sources might play in interpretation.

\section{Extratextual Evidence of Meaning (Communicative Content)}

Interpretation aims to recover the communicative content of the text in context. In some cases, the interpretive enterprise is easy. We can discern the semantic context of the text because we are competent speakers of the natural English language; in many cases, the semantic content of the Constitution is easily accessible because the words and phrases used at the time the provision was drafted have the same meanings today. Frequently, we know enough about context without investigation. But in other cases, the meaning of the text will be relatively inaccessible. The meaning of the words may be unfamiliar, or we may need to know more about context.

Extratextual sources can aid interpretation. First, extratextual sources can provide evidence of the conventional semantic meaning of the words and phrases that comprise the constitutional text. Evidence of the meaning of the phrase "legislative power" might be found in the Federalist Papers or in the institutional practices of the Continental Congress or the early Congresses of the United States. An understanding of the ethos of the founding era might aid in discerning the meaning of the phrase "freedom of speech," or we might look to the legal practice of the founding era for an elucidation of the notion of "freedom of the press." Of course, if we are original public-meaning originalists, we will be looking for two particular kinds of evidence-evidence of conventional semantic meanings or evidence of enrichment from the publicly available context of communication.

\section{Extratextual Contributions to Constitutional Constructions Bound to the Text}

The Constitution of the United States includes a variety of provisions that are general and abstract; some of these are vague or opentextured. These provisions may have a core of settled meaning, but to the extent that they are vague, they will have a penumbra-the space of possible cases where the communicative content of the text underdetermines legal content and effect. We can call this space, "the construction zone." In the construction zone, the linguistic meaning of the text cannot tell us how to decide particular cases. Constitutional construction that goes beyond translation of communicative content into legal content will 
be required. ${ }^{33}$ When constitutional construction operates within a construction zone created by the constitutional text, we can say that the construction is "bound to the text." 34

Theories of constitutional interpretation provide an account of the communicative content of the constitutional text. Theories of constitutional construction are different-they are normative theories about what we ought to do with that content. Characteristically, originalist theories of constitutional construction will respect the constraint principle-they will only sanction constructions that are consistent with the communicative content of the text. In easy cases, construction may take place without resort to extratextual sources - the text may be sufficient to provide the legal content that resolves the cases. ${ }^{35}$ But in hard cases, even originalists may resort to extratextual sources to provide legal content.

Consider the First Amendment freedom of speech. Because the text is general, abstract, and vague, we are in the construction zone. In a particular case, more than one outcome may be consistent with the communicative content of the constitutional text. If we look to free speech doctrine as a whole, there are multiple versions of the doctrine that are consistent with the communicative content of the doctrine. This means that we will need to look outside the four corners of the text and the publicly available content of constitutional communication to resolve at least some possible cases that could arise under the First Amendment freedom of speech.

For example, we might attempt to formulate a theory of free expression that gives more definite content to the phrase "freedom of speech." In formulating that theory, we might consider a variety of extratextual sources. We might look directly to more general theories of political morality: Ronald Dworkin advocates a method of this kind. ${ }^{36}$ Or we might look to the political morality of the founding generationthe free speech ethos of late eighteenth-century America. Or we might instead look to the free speech values that characterize America today.

33. Solum, supra note 25.

34. The phrase "bound to the text" is being used in a stipulated sense. Constructions that are bound to the text are stipulated to be constructions that operate within the zone of underdetermination created by vague or irreducibly ambiguous terms.

35. In some cases, this will mean that the legal content of constitutional doctrine will be sufficiently determined by the communicative content of the text to determine the outcome of the case. In such cases, the activity of construction consists in translating the communicative content of the text into the equivalent legal content (or constitutional doctrine). These are likely to be "easy cases," and because they are easy, the activity of construction may go unnoticed or seem automatic. See Solum, supra note 25.

Here is an example: Article One provides that each state shall have two senators. U.S. CONST. art I, $\S 3$, cl. 1. Because senators are human beings, borderline cases do not arise. Senators Boxer and Feinstein are two senators - not one or three. Constitutional construction is at work here - the constitutional practice (which determines legal effect) is to follow the original meaning of the Constitution. It could be otherwise; someone might advocate for an amending construction that reapportioned the Senate by population. But on this particular issue, living constitutionalists and originalists are united in (tacitly or consciously) endorsing the constraint principle.

36. RONALD DWORKIN, LAW'S EMPIRE (1986). 
Or we might attempt to discern the theories of freedom of speech that were implicit in the institutional practices of the Founding Era.

This Article does not explore the justifications for originalism. Rather, the Article simply assumes an originalist perspective (with public meaning originalism as the model case). But when it comes to originalist theories of constitutional construction, the underlying justification for originalism can and likely will make a difference. Theoretical consistency will demand that the originalist theory of constitutional construction cohere with the underlying normative justification for the constraint principle. If the constraint principle is justified by an account of popular sovereignty, then the theory of constitutional construction must be consistent with popular sovereignty (in light of other relevant political values). If the constraint principle is justified by rule-of-law considerations, then the theory of constitutional construction must be consistent with the rule of law (or departures must be justified by other salient political values).

Thus, the requirement of theoretical consistency has implications for the way in which particular originalist theories treat the various categories of extratextual sources. If the constraint principle were justified by rule of law consideration and a distrust of the institutional capacity of judges to make objective morally-correct decisions, then the theory of constitutional construction would do well to avoid a reliance on the judges' own beliefs about political morality. If the constraint principle is justified by popular sovereignty theory, then it might follow that the social norms and values of "We the People" today should play a role in constitutional construction. Of course, these are only toy examples-working up a full-fledged theory of constitutional construction cannot be accomplished on this occasion. The toy examples are provided for illustration only-to show how the requirement of theoretical constraint might operate for particular versions of originalism.

\section{Extratextual Sources of Constitutional Norms Not Bound to the Text}

We have just considered the possibility that extratextual sources might be used to flesh out the content of constitutional constructions that are bound to the text. But it is at least theoretically possible that there might be constitutional constructions that are "freestanding" or "unbound" - that cannot be connected to the zone of underdetermination created by a particular clause or to the structure of the Constitution as a whole or in part.

To illustrate this idea, we can pursue a counterfactual hypothetical. Suppose that the Constitution had absolutely nothing to say about unenumerated rights. Imagine, for example, that the Ninth Amendment had not been ratified and that the Fourteenth Amendment did not contain any provision with communicative content that provides a textual basis for unenumerated rights. (Suppose for example the Fourteenth Amendment had not included "due process," "equal protection," or 
"privileges or immunities.") Could originalists nonetheless endorse constitutional constructions that created judicially enforceable unenumerated rights?

The answer to this question will depend on the content of the particular version of originalism. Originalism's two core ideas, the fixation thesis and the constraint principle, do not tell us whether unbound unenumerated rights are permissible. Although the general formulation of the constraint principle itself does not answer our question, there are particular versions of the constraint principle that do. Consider the view that we have dubbed "super strict construction." On that view each and every judicially enforceable rule of constitutional law must directly translate the communicative content of the constitutional text: this version of the constraint principle might be called "constraint as equivalence." At the opposite end of the spectrum, consider a version of the constraint principle that requires only consistency-constitutional doctrine must not contradict the communicative content of the text: we might call this version, "constraint as consistency." Constraint as consistency would allow for constitutional doctrine that is a superset of those doctrines that are required by the communicative content of the text. Finally, the constraint principle might be interpreted in light of the notion of boundedness. This version of the principle would limit legitimate constitutional construction to those constructions that are within the construction zones created by particular clauses or the constitutional structure: we might call this version "constraint as boundedness." So we have three different versions of the constraint principle, with different implications for the legitimacy of resort to extrajudicial sources that are not bound to the text.

We have now categorized extrajudicial sources and the roles they might play in the activities of constitutional interpretation and construction. This completes our investigation of extratextual sources at the level of abstraction. The next phase of our investigation will examine particular sources and the role that they should play in constitutional interpretation and construction - from an originalist perspective.

\section{ORIGINALISM AND EXTRATEXTUAL CONSTITUTIONAL CONTENT}

We have now established a theoretical framework that will enable us to examine the role of extratextual sources in constitutional interpretation and construction from an originalist perspective. Recapitulating briefly, we have: (1) identified the core of contemporary originalist theory, (2) marked the distinction between interpretation and construction, (3) identified the construction zone, (4) categorized extratextual sources, and (5) specified the different roles that these sources might play in constitutional interpretation or construction. We can now apply this framework to particular types of constitutional argument. In each case, we will examine the type and then consider its relationship to the proper attitude of originalism toward the use of extratextual sources in constitutional interpretation and construction. 


\section{A. Constitutional Implications}

The Constitution may "imply" things that it does not say. Let us call the content that is implied but not stated "constitutional implication." Some theorists treat constitutional doctrines that are derived or discovered by "implication" from the constitutional text as examples of an unwritten constitution. For example, Akhil Amar, in his book America's Unwritten Constitution, suggests that we "read between the lines of the Constitution-to see what principles are implicit in the document, read as a whole, even if these principles are nowhere explicitly stated in any specific clause." ${ }^{37}$ The word "implicit" is the adjective form of the verb "implied" and the corresponding noun "implication." An "implication" is a conclusion that can be drawn from something, although it is not explicitly stated.

In this section we are investigating "constitutional implication." Before we proceed further, we should note a terminological difficulty. The term "implication" can be used to refer to a variety of linguistic phenomena. For example, "implication" may be used as a synonym for "logical implication" or "entailment." But we might also use the word "implication" to refer to certain forms of contextual enrichment: in the philosophy of language and theoretical linguistics special terminology is used to distinguish the distinct phenomena covered by the umbrella word "implication." Thus, implication can be distinguished from "implicature," 38 "impliciture," ${ }^{39}$ and so forth. More on those below, but for now we shall stipulate that the word "implication" is used to refer to logical implication or entailment.

Everyone understands that legal texts have logical implications. We can express these implications in simple syllogisms:

Premise 1: "The Senate of the United States shall be composed of two Senators from each State." 40

Premise 2: Alaska is a state.

Conclusion: $\therefore$ Alaska is entitled to two senators.

The text of the Constitution does not mention Alaska, but from what the text does say and from the true factual premise that Alaska is a state, we can imply that Alaska is entitled to two senators.

This account of constitutional implication is not quite right. The first premise is a quote from the text of Article I and the Seventeenth Amendment. Premise two is a fact. The conclusion is a rule of law. Strictly speaking, the argument needs an additional step or two-which move from the text to the communicative content and then to the associated legal content. We can easily imagine an expanded version of the syllogism that fills in the missing steps.

37. AMAR, supra note 5, at xv

38. See infra text accompanying note 41 .

39. See infra note 45

40. U.S. CONST. art I, § 3, cl. 1. 
What is absolutely clear is that originalism should endorse constitutional implication as a general method of constitutional construction. Constitutional implications are not in the text, but they follow from the text.

\section{B. Contextual Enrichment}

We have already introduced the idea of contextual enrichment. For public-meaning originalists, the public meaning of the text is produced by the semantic content of the text as enriched by the publicly available context of constitutional interpretation. Contextual enrichment happens in various ways, and a complete typology is outside the scope of what can be accomplished on this occasion. Nonetheless, it is important to note that some forms of contextual enrichment may be called "implications" in ordinary English. But since we are limiting the use of the term "implication" to the stipulated sense of logical implication or entailment, we need a richer vocabulary to describe some of the forms of contextual enrichment.

On this occasion, we shall investigate one form of contextual enrichment, which we shall call "implicature," using the word coined by the philosopher Paul Grice. ${ }^{41}$ One way to get at the notion of implicature is to distinguish it from implication. Here is how Kent Bach expresses the distinction:

The difference [between implication and implicature] is fundamental. If a sentence is true, what it implies must be true, whereas a speaker can utter a true sentence and implicate something false. For example, you could say that there's a gas station around the corner and falsely implicate that it's open and selling gas (maybe it's closed for the night or maybe there's a gasoline shortage). If there's a gas station around the corner, it doesn't follow that the gas station is open and selling gas. But it does follow that the gas station is not directly across the street. ${ }^{42}$

Implications flow logically. Implicatures are communicated by utterances in context. To elaborate, consider the following exchange:

Ben: Where can I buy some gas?

Alice: There is a gas station around the corner.

Alice did not say, "You can buy gas at the station around the corner," but in context, what she did say creates an implicature to that effect. Or consider the classic example of a letter of recommendation-by a professor and for a former student who is applying for a tenure-track faculty position. The letter says, "Ben attended class with regularity, and was unfailingly punctual," and nothing else. This statement has no logi-

\footnotetext{
41. Wayne Davis, Implicature, STAN. ENCYClopedIA OF PHIL. (2010), http://plato. stanford.edu/entries/implicature/.

42. Kent BACH, The Top 10 Misconceptions About Implicature, in DRAWING THE BOUNDARIES of Meaning: NeO-Gricean Studies in Pragmatics and Semantics in Honor of LaURence R. HORN 21, 22 (Betty J. Birner \& Gregory Ward eds., 2006).
} 
cal implications regarding Ben's suitability for a tenure-track job, but given the context, the implicature is that Ben is completely unsuitable. If the best you can say about Ben is that his attendance was regular and punctual, the implicature is that in other dimensions he must fall woefully short.

Implicature is a general phenomenon that occurs in a variety of communicative settings, but we are concerned with a special category of legal implicature, which we can call "constitutional implicature." ${ }^{33}$ The question at hand is whether originalists should endorse the idea that constitutional implicatures contribute to the communicative content bound to particular constitutional provisions (or to the constitutional structure). The answer to that question would appear to be "yes." The version of public-meaning originalism that we have examined as our model case is fully consistent with the constitutional implicature as a method for constitutional interpretation. Constitutional implicature goes beyond semantic content; if the meaning of the Constitution were limited to its semantic content, its meaning would be very sparse-we would read the Constitution as if we knew nothing about the context in which it was framed and ratified. Depriving ourselves of all knowledge of context produces a "stripped down Constitution." We wouldn't know whether the Constitution had been adopted in the United States in the eighteenth century, as opposed to being a fictional constitution in an alternative history novel. We would know nothing of the Articles of Confederation, the Revolutionary War, or English common law.

The public meaning of the Constitution is not the meaning of the stripped-down Constitution. For public-meaning originalism, the aim is to recover the full communicative content of the Constitution - the linguistic meaning as enriched by the publicly available context of constitutional communication. Constitutional implicatures arise from the publicly available context of constitutional communication.

Consider for example, the enumerated power "to establish post offices and post roads." 44 The semantic content of the Post Clause does not include a power to carry and deliver the mail: only the offices and roads are authorized. And we cannot get from offices and roads to delivery by constitutional implication (logical necessity). It is logically possible to have the former powers without the latter. This is easily demonstrable as we can imagine a logically consistent version of the postal power that reads as follows: "Congress shall have the power to establish post offices and post roads, but the several states shall organize services for the delivery of the mail from the post offices to homes and businesses."

The power to deliver mail is neither stated explicitly nor logically implied, but no one doubts that the postal power includes the power to

43. See Solum, supra note 18, at 56-57 (coining the phrase "constitutional implicature"); see also Randy E. Barnett, The Misconceived Assumption About Constitutional Assumptions, 103 NW. U. L. REV. 615, 624-25 (2009).

44. U.S. CONST. art. I, $\S 8$, cl. 7. 
deliver the mail. That power is part of the communicative content of the Post Clause, because it follows from the clause as a matter of constitutional implicature. ${ }^{45}$ Precisely this sort of implicature was the basis of John Marshall's statement in McCulloch v. Maryland: the explicit power "to establish post offices and post roads" creates an implicated power "of carrying the mail along the post road, from one post office to another." 46 As Ryan Williams observes, "Even without the Necessary and Proper Clause, the implication of such a power would likely have struck most observers as so natural and obvious that a narrower interpretation denying such a power would have seemed absurd." ${ }^{47}$ (Note that Williams is using the word "implication" in the broad sense that includes implicatures.)

Deep and interesting questions remain for originalists. In particular, originalists should investigate the mechanics and mechanisms of constitutional implicature. In this regard, Williams's work is pioneering. After recognizing the legitimacy of constitutional implicature, ${ }^{48}$ Williams suggests the following criterion:

[I]f the implied content is not semantically encoded in the text, interpreters should inquire whether a reasonable member of the ratifying public at the time of enactment would have recognized the implied content as following obviously and noncontroversially from the choice of the particular language used in the provision and the relevant background context. ${ }^{49}$

Further refinements may be required. The notion of a "reasonable member of the ratifying public" is a legal notion. But the question that we are asking is not a legal question -it is a question about meaning. So we might substitute "competent speaker of American English" for "reasonable member." Williams uses the phrase "implied content," but this usage runs the risk of conflating implication and implicature. We might substitute, "implicated content." Williams suggests that constitutional implicature be limited to content that is obvious and noncontroversial, but it is not clear that this is the way that implicature always works. Sometimes the communicative content of a text may not be "obvious"-

45. I am using "implicature" in a broad sense that encompasses a variety of more particular forms of contextual enrichment. In the case of postal roads and the power to deliver the mail, the precise form of contextual enrichment may be "impliciture": something that is "implicit" goes without saying or is implicit in what is said. See Kent Bach, Conversational Impliciture, 9 MIND \& LANGUAGE 124-162 (1994).

46. 17 U.S. (4 Wheat.) 316, 417 (1819).

47. Ryan C. Williams, The Ninth Amendment as a Rule of Construction, 111 COLUM. L. REV. 498, 543-44 (2011). I have adapted the Postal Clause example from Williams's elegant and important article.

48. Id. at 544. Williams's discussion of this point is somewhat misleading given the technical way that "implication" and "implicature" are used in the relevant literature. He suggests that constitutional implications should be recognized if "the putatively implied content arises as a matter of logical necessity due to a noncancellable, semantically encoded formulation." Id. This formulation is correct, but Williams characterizes this principle as a component of a test "for recognizing constitutional implicatures." Id. That characterization is inaccurate. The logical consequences of semantic content are implications, not implicatures. See BACH, supra note 42, at 26.

49. Williams, supra note 47 , at 544 . 
it may be that competent speakers would need to read carefully to see the implicature. Likewise, the existence of controversy does not automatically cancel an implicature. Interpretation and construction of legal texts, and especially of the Constitution, involve motivated reasoning; vested interests or passionate ideologues may create controversy about implicatures that would be recognized by competent speakers motivated by a desire to understand the text. As a matter of constitutional interpretation, the question is whether the implicature is correct and not whether it is disputed.

We might reformulate Williams's proposed principle as follows:

Constitutional implicatures arise when competent speakers of the language at the time the constitutional provision was framed and ratified would draw the implicature from the text given the publicly available context of constitutional communication.

Further questions remain. Implicature gives rise to special cases of vagueness and ambiguity. When an implicature has vague content, the implicature creates a construction zone-the content of the implicature is not sufficient to resolve the case: constitutional construction will be required. Another possibility is that competent speakers with knowledge of the publicly available context of constitutional communication would disagree about what the content of the implicature is. This is a special case of ambiguity, "implicative ambiguity." Usually semantic ambiguity can be resolved by reference to context, in the case of implicative ambiguity, context creates the ambiguity. Of course, it might be the case that the ambiguity appears when some subset of the publicly available context of constitutional communication is considered, but resolves in light of the full context. But it is at least theoretically possible that ambiguity is irreducible, and hence that constitutional construction will be required.

We can imagine a variety of possible approaches to construction when an irreducible implicative ambiguity exists. We can explore this problem in the context of its most famous exemplar-the Ninth Amendment.

\section{The Ninth Amendment}

The Ninth Amendment to the U.S. Constitution states, "The enumeration in the Constitution, of certain rights, shall not be construed to deny or disparage others retained by the people." We can begin with the word "construed." The Ninth Amendment is a rule of construction in the technical sense. This is not a product of the perhaps fortuitous use of "construed" which is a form of the same root word as "construction." Rather, it follows from the interpretation-construction distinction and the implication-implicature distinction. The Constitution enumerates certain rights in Sections 9 and 10 of Article I, in Article IV, and in various amendments, including the first eight provisions of the Bill of Rights, and subsequent to the Ninth Amendment in various other amendments, including the Fourteenth Amendment. As a matter of interpretation, the 
enumeration of these rights could not give rise to a constitutional implicature that denied or disparaged other rights retained by the people. The semantic content of the enumerated rights consists of positive statements about the right in question - freedom of speech, the right to bear arms, and so forth. The fact of enumeration is a structural feature of the Constitution. Nothing in the semantic content of the rights contains a semantic content that explicitly denies or disparages other rights retained by the people. But it is at least possible that the communicative content of the enumeration of particular rights gives rise to an implicature that denies or disparages other rights. The reasoning would go as follows:

The Constitution enumerates a list of particular rights of the people. The point of enumerating particular rights (and omitting a more general statement) is to create an exhaustive list. Therefore, the enumerated rights are the only rights retained by the people.

The semantic content of the Ninth Amendment forbids this form of implicature, and it would forbid this implicature even if the implicature best captured the public meaning of the Constitution as it would have been without the Ninth Amendment. But the semantic content does a second thing. Even if enumeration did not give rise to an implicature of exclusivity, there could be a constitutional doctrine (legal content) that forbade judicial enforcement of unenumerated rights. The reasoning in favor of such a rule of constitutional construction might have proceeded as follows:

The Constitution enumerates a list of particular rights of the people. This enumeration could give rise to an inference of exclusivity or it could give rise to an opposing inference that other relevantly similar rights are also protected. This implicative ambiguity requires constitutional construction. The better construction (for normative reasons that the reader can supply) is that the list is exclusive. Therefore, there should be a rule of constitutional doctrine that limits individual rights to those that are enumerated and those that result by logical implication from the enumerated rights.

The semantic content of the Ninth Amendment forbids this construc$\operatorname{tion}^{50}$ (and also the interpretation already considered), and hence the Ninth Amendment is itself a rule of construction.

Thus far we have focused on the semantic content of the Ninth Amendment, but most of the debate about the meaning of the Ninth concerns implicature and other forms of contextual enrichment. Again consider the text: "The enumeration in the Constitution, of certain rights, shall not be construed to deny or disparage others retained by the people." The text does not state that the people do have retained rights. This can be demonstrated by adding the words "if any" to the text as follows: "The enumeration in the Constitution, of certain rights, shall not be construed to deny or disparage others, if any, retained by the people."

50. See id. at 533; see also Kurt T. Lash, A Textual-Historical Theory of the Ninth Amendment, 60 STAN. L. REV. 895, 929 (2008). 
The "if any" does not create a logical contradiction. For this same reason, the semantic content of the text does not give rise to a constitutional implication that the people have retained rights - it is not logically required by the semantic content.

But the Ninth Amendment does give rise to a straightforward constitutional implicature that the people retain other rights. The reasoning is simple. There would be no reason for the Ninth Amendment if there were no rights retained by the people; given what the Ninth Amendment does say and the publicly available context of constitutional communication, a competent speaker of English would draw the implicature. And hence the implicature is part of the communicative content of the Ninth Amendment. Given the constraint principle, public meaning originalists ought not endorse constitutional doctrine that is inconsistent with the implicature-assuming that no defeasibility condition comes into play.

Having gotten this far, there is a further question: what is the content of the retained rights? Immediately, we see a problem. The constitutional implicature is that there are retained rights, but this implicature from the Ninth Amendment does not tell us what the content of the rights might be. Of course, it is possible that the publicly available context of constitutional communication provides sufficient information to give shape to that content. For example, if that context included widespread public agreement on a theory of natural rights such that competent speakers of American English immersed in the political culture would understand that "retained rights" were natural rights, then the publicly shared theory of natural rights might liquidate a substantial amount of the implicated vagueness. Similarly, if the shared culture included agreement on theories of popular sovereignty or of federalism, then one of those theories might similarly provide content to the implicature. Many of the debates about the meaning of the Ninth Amendment should be understood as debates about the content of the publicly available context of constitutional communication.

Suppose, however, that the publicly available context included competing and only partially articulate views about natural rights, popular sovereignty, and federalism. In that case, the content of the constitutional implicature from the Ninth Amendment might be irreducibly ambiguous. Operationally, this would be the case if different competent speakers aware of the public context would draw different inferences about the content of the constitutional implicature or if a single reader would be undecided about the content of the implicature. Such irreducible ambiguity requires constitutional construction.

But that is not the end of the story. It might be that the irreducible ambiguity is only partial. Consider the following example: the First Amendment begins "Congress shall make no law" and hence one might conclude that the "freedom of speech" binds only Congress-leaving the executive and judicial branches unrestrained. But the Ninth Amendment juxtaposed with the First Amendment and publicly available context of 
constitutional communication may give rise to a constitutional implicature that the freedom of speech also constrains action by the executive and judicial branches. This is simply one example of a more general phenomenon-irreducible ambiguity in the content of constitutional implicatures can be partial or total. If it is partial, then the constraint principle suggests that originalists should honor that portion of the implicature that is unambiguous.

\section{Extratextual Constructions of Written Clauses}

Implicature and the Ninth Amendment are difficult both theoretically and practically, but there are much easier cases. Some provisions of the Constitution have vague communicative content. For example, the clauses that vest "legislative," "executive," and "judicial power" may be vague in this way. ${ }^{51}$ Of course, vague semantic content may become relatively more determinate once context is taken into account, but for many constitutional provisions, it seems likely that a substantial construction zone will remain after contextual enrichment.

Different versions of originalism can embrace different theories of constitutional construction so long as those theories are consistent with the fixation thesis and the constraint principle-the unifying principles (or core) of originalism. Some originalists may adopt theories of construction that maximize the authority of the political branches; for example, they might adopt a general rule of construction that calls for judges to defer to the political branches in the construction zone. ${ }^{52}$ Other originalists might look to the judicial practice of the founding era; the theory that is called "original methods originalism" could serve this purpose. ${ }^{53}$ And another group of originalists might look to multiple modalities of constitutional argument, including text, history, structure, precedent, "ethos" of the American social order, and prudence. ${ }^{54}$ The content of any particular originalist theory of construction will depend on the underlying normative justification that theory gives for the constraint principle and a variety of other factors.

51. U.S. CONST. art I, § 1; id. art II, § 1, cl. 1; id. art III, § 1 .

52. See Gary Lawson, Dead Document Walking, 92 B.U. L. REV. 1225, 1233 (2012); Michael Stokes Paulsen, Does the Constitution Prescribe Rules for Its Own Interpretation?, 103 Nw. U. L. REv. 857, 903 n.141 (2009); see also Solum, supra note 25.

53. See generally John O. McGinnis \& Michael B. Rappaport, Original Methods Originalism: A New Theory of Interpretation and the Case Against Construction, 103 Nw. U. L. REV. 751 (2009) (advancing their theory as one of construction and not of interpretation); Solum, supra note 25.

54. The modalities approach is associated with Philipp Bobbitt, who is not an originalist. See PhILIP BobBitT, CONSTITUTIONAL INTERPRETATION 12-13 (1991). Whereas Bobbitt believes that all the modalities are relevant to constitutional interpretation (which he does not differentiate from constitutional construction), an originalist might adapt Bobbitt's approach as a theory of constitutional construction. See Solum, supra note 25. Stephen Griffin's pluralist approach to constitutional interpretation is similar to Bobbitt's modalities account. See Stephen M. Griffin, Pluralism in Constitutional Interpretation, 72 Tex. L. Rev. 1753, 1753 (1994). 


\section{E. Holism and Structure}

In America's Unwritten Constitution, Akhil Amar suggests an approach to what he calls an "unwritten Constitution" and what I call extratextual sources of constitutional interpretation and construction. Although the primary focus of the book is on particularities, he does articulate a general method:

A single methodological idea unifies all the foregoing case studies and hypotheticals. On each topic, clause-bound literalism fails. Sometimes the key clause in isolation is simply indeterminate. (The phrase "executive Power" can be read narrowly or broadly on the issue of presidential immunity from prosecution.) Other times, the most salient clause, in isolation, sends a rather misleading message. (The First Amendment speaks only of "Congress," but surely presidents, federal courts, and states must also honor citizens' rights to express political opinions.) On occasion the Constitution's true meaning is very nearly the opposite of what the applicable clause seems to say quite expressly. (The vice president does not properly preside over his own impeachment.) This Article's unifying idea is that we must read the Constitution as a whole-between the lines, so to speak. ${ }^{55}$

Let us use the name "constitutional holism" for the view that the meaning of the Constitution is the meaning of the whole document or the "holistic meaning." W6 What should originalists think about holism?

Public-meaning originalists are committed to the public-meaning thesis. The communicative content of the Constitution is a function of contextually enriched semantic content. But what if individual words and phrases cannot be understood in isolation because the Constitution is an organic whole? For example, the phrase "rights... retained by the People" in the Ninth Amendment might not be comprehensible without reference to "We the People" in the Preamble: are "the People" individuals or are they a polity? Likewise, the Ninth uses the phrase "the enumeration of certain rights in this Constitution." Gleaning the meaning of this phrase seems to require reference to what is now called "the Bill of Rights," and once that has been accomplished, the meaning of the phrase "rights ... retained by the People" may be clarified. For example, the "retained rights" which are not to be denied or disparaged may be of the same type or kind as the "enumerated rights" such as the freedom of speech and press, the right to bear arms, the right to due process, and so forth.

Does holistic meaning provide a better account of the communicative content of the Constitution than does public meaning (as specified

55. AMAR, supra note 5, at 47 (emphasis added).

56. See, e.g., Akhil Reed Amar, A Few Thoughts on Constitutionalism, Textualism, and Populism, 65 FORDHAM L. REV. 1657, 1659 (1997) (observing "the importance of looking at the Constitution as a whole, because what was ratified was the document, not individual clauses" and "[t]he clause is not the unit, or at least the only unit of analysis"). 
here)? To get at this question, we first need to identify and then deflate a misleading picture of the relationship between the meaning of individual clauses and the whole Constitution. It might be thought that there are only two alternative positions on the relationship of the whole to the parts when it comes to constitutional meaning. The first alternative might be called "clause-bound interpretivism," which we can define as follows:

The meaning of each clause must be determined from within the four corners of the clause.

Akhil Amar suggests and rejects this alternative throughout the text of America's Unwritten Constitution. ${ }^{57}$ We can now see that clausebound interpretivism is inconsistent with the public meaning thesis: the meaning of the Constitution for the public (at the time of framing and ratification) is a function of both semantic content and context. So public-meaning originalists should reject clause-bound interpretivism.

This brings us to a second theory, which might be called "organicunity holism":

Meaning only attaches to the whole Constitution as an organic unity; as a consequence individual clauses are not meaningful units of constitutional communication. ${ }^{58}$

This picture, which suggests we must choose between clause-bound interpretivism and organic-unity holism, might be called the "all-ornothing picture": either the Constitution's meaning is all holistic (the whole Constitution all at once) or it is nothing holistic (no meaning attaches to the individual clauses by virtue of their relationship to the whole document).

The all-or-nothing picture creates a false dilemma. There is an alternative picture of the relationship between the meaning of individual clauses and the whole Constitution: that picture can be expressed via two theoretical ideas: (1) the familiar device of the hermeneutic circle, and (2) the related notion of intratextualism.

The idea of the hermeneutic circle figured prominently in Protestant theological hermeneutics as a method for understanding the relationship of the meaning of individual biblical passages to the whole text: "the meaning of each individual passage of scripture is gleaned in

57. See, e.g., AMAR supra note 5, at 47.

58. Organic unity holism resembles "semantic holism," a position in the philosophy of language. Ned Block defines semantic holism as follows:

Mental (or semantic) holism is the doctrine that the identity of a belief content (or the meaning of a sentence that expresses it) is determined by its place in the web of beliefs or sentences comprising a whole theory or group of theories. It can be contrasted with two other views: atomism and molecularism. Molecularism characterizes meaning and content in terms of relatively small parts of the web in a way that allows many different theories to share those parts. For example, the meaning of 'chase' might be said by a molecularist to be try to catch. Atomism characterizes meaning and content in terms of none of the web; it says that sentences and beliefs have meaning or content independently of their relations to other sentences or beliefs.

Ned Block, Holism, Mental and Semantic, in RouTLEDGE ENCYLOPEDIA OF PHIL. (forthcoming 2013), available at http://www.nyu.edu/gsas/dept/philo/faculty/block/papers/MentalSemanticHolism.html. 
light of the meaning of the Bible as a whole." ${ }^{59}$ As Gadamer puts it, "For the whole of Scripture guides the understanding of individual passages: and again this whole can be reached only through the cumulative understanding of individual passages." ${ }^{60}$ Justice Story's first recommendation for constitutional construction is based on the same notion: "In construing the constitution of the United States, we are, in the first instance, to consider, what are its nature and objects, its scope and design, as apparent from the structure of the instrument, viewed as a whole, and also viewed in its component parts."

Intratextualism ${ }^{62}$ as articulated by Akhil Amar expresses a closely related idea with a different metaphor:

Textual argument as typically practiced today is blinkered ("clause-bound" in Ely's terminology), focusing intently on the words of a given constitutional provision in splendid isolation. By contrast, intratextualism always focuses on at least two clauses and highlights the link between them. Clause-bound textualism paradigmatically stresses what is explicit in the Constitution's text: "See here, it says X!" By contrast, intratextualism paradigmatically stresses what is only implicit in the Constitution's text: "See here, these clauses fit together!" But there is no clause in the Constitution that says, explicitly and in so many words, that the three Vesting Clauses should be construed together, or that the Article III grant of federal question jurisdiction should be read alongside the Article VI Supremacy Clause. Intratextualism simply reads the Constitution as if these implicit linking clauses existed. Clausebound textualism reads the words of the Constitution in order, tracking the sequence of clauses as they appear in the document itself. By contrast, intratextualism often reads the words of the Constitution in a dramatically different order, placing textually nonadjoining clauses side by side for careful analysis. In effect, intratextualists read a two-dimensional parchment in a threedimensional way, carefully folding the parchment to bring scattered clauses alongside each other. ${ }^{63}$

Both the idea of the hermeneutic circle and the idea of intratextualism undermine the all-or-nothing picture. Our choices are not limited to clause-bound interpretivism and organic-unity holism. The excluded middle is to read individual clauses in the context of the whole Constitution. Public meaning originalism squarely occupies the excluded middle: it insists that the semantic content of individual clauses is enriched by the publicly available context, and the whole of the constitutional text is in-

59. Lawrence B. Solum, Originalism As Transformative Politics, 63 TUL. L. REV. 1599, 1608 (1989).

60. Hans-Georg Gadamer, Truth And Method 175 (1975) (Joel Weinsheimer \& Donald G. Marshall trans., 2d ed. 1992).

61. Joseph Story, Commentaries on the Constitution of the United States 136 (abridged ed. 1833).

62. See Akhil Reed Amar, Intratextualism, 112 HARV. L. REV. 747 (1999).

63. Id. at 788 (citations omitted). 
disputably part of that! Moreover, public meaning originalism endorses the idea that contextual enrichment may occur at the structural level, that is, the "structural features of the constitutional text." ${ }^{64}$ Once the allor-nothing picture is out of the way, it becomes apparent that contextual clause meaning can be reconciled with a plausible version of holistic meaning.

One final point: organic unity holism is utterly implausible as a theory of communicative content. The whole Constitution is not the relevant unit for determining communicative content. It is no accident that when we apply the Constitution, our focus is on clauses, the interaction between clauses, and the structural features that form such interactions. The Constitution as an organic unity says both too much and too little. Too much, because the whole Constitution from top to bottom considered a single unit of meaning does not translate into rules of constitutional law: organic unity holism makes the Constitution one long primal scream. Too little, because organic unity prevents us from assigning meaning at the level of particularity required to do the work of constitutional practice: organic unity holism transforms individual clauses into meaningless concatenations of phonemes.

In sum, if holistic meaning is construed plausibly (as incorporating the ideas of the hermeneutic circle and intratextualism) then it is absorbed into public meaning originalism. But if construed in accord with organic unity holism, holistic meaning is no meaning at all.

Can originalists embrace modest holism? Modest holism can play at least four distinct roles in constitutional interpretation and construction:

1. Reading parts of the Constitution in light of the whole can resolve semantic ambiguities.

2. Reading parts of the Constitution in light of the whole can reveal constitutional implications - the logical consequences of the interactions between various clauses.

3. Reading parts of the Constitution in light of the whole can create or reveal contextual enrichment-in this regard the whole text acts as context for particular clauses, phrases, or words.

4. Reading parts of the Constitution in light of the whole can guide constitutional construction; for example, the relationship between the grants of legislative, executive, and judicial power in the first three Articles could guide construction of each.

Originalists can and should endorse modest holism whenever it plays one of these four roles.

64. See supra text accompanying note 31 . 


\section{G. Extratextual Fundamental Law}

Extratextual sources can play yet another role-as freestanding sources of fundamental law. The concept represented by the word "freestanding" plays an important role here. We can begin to understand the notion of "freestanding fundamental law" by way of contrast with two other ideas: (1) the constitutional constructions that are bound to text and (2) contextual enrichment of the semantic content of the text. Constructions that are bound to the text are not freestanding - they are attached to text that is vague or irreducibly ambiguous. Contextual enrichments (e.g., constitutional implicatures) provide the communicative content of the text in context; they do not stand free from the text.

But we can imagine constitutional doctrine that is derived from freestanding sources. For example, one might believe that fundamental principles of political morality operate directly to create constitutional doctrine. The strongest version of this idea would give these principles of political morality trumping force - they would have legal force even if directly contrary to the text of the Constitution. Consider an example: slavery and the slave trade both violate fundamental principles of political morality, but the text of the Constitution arguably prohibited Congress from outlawing the slave trade. ${ }^{65}$ A more modest version would allow for fundamental law that supplements but does not contradict the constitutional text. For example, one might believe that there is a principle of political morality that is the source of a constitutional rule forbidding capital punishment-even though the communicative content of the Constitution does not contain or imply such a rule. ${ }^{66}$

We have already discussed the Ninth Amendment. Although the Amendment itself does not directly or logically imply or state that extratextual fundamental law is judicially enforceable, it might be that the Ninth Amendment creates a constitutional implicature to that effect. That argument would not be "freestanding" in the sense in which that term is used here. For the sake of argument, we need to assume that neither the Ninth Amendment nor any other textual source provides a textual basis for the incorporation of extratextual fundamental law.

What should be the stance of originalism toward extratextual fundamental law as a freestanding source of constitutional law? The constraint principle suggests that the strong version of the idea of extratextual fundamental law is inconsistent with originalism. But what about the modest version? One tempting answer implicitly invokes the idea that the Constitution is an integrated writing, but where would that prin-

65. U.S. CONST. art. I, § 9 ("The Migration or Importation of such Persons as any of the States now existing shall think proper to admit, shall not be prohibited by the Congress prior to the Year one thousand eight hundred and eight, but a Tax or duty may be imposed on such Importation, not exceeding ten dollars for each Person.").

66. Of course, some opponents of capital punishment could argue that a rule forbidding the death penalty can be derived from the Eighth Amendment to the Constitution. The argument in text is based on the assumption that this derivation does not work. 
ciple come from? It is not stated in the constitutional text nor is it logically implied by the text. ${ }^{67}$ Putting the Ninth Amendment to the side, the text takes no position on extratextual fundamental law.

Of course, many originalists will believe that extratextual fundamental law is obviously contrary to the normative basis for the constraint principle. For example, if one affirms the constraint principle because one believes that judges are untrustworthy and hence should be constrained by the constitutional text, one will be likely to adopt a rule that prohibits judicial recognition and enforcement of extratextual fundamental law. But this rule itself is not stated in the text. It might be a construction derived from the phrase "judicial power" or it might itself be derived from a freestanding principle of political morality.

On the other hand, if one's justification for the constraint principle were based on a theory of natural rights combined with an argument that public meaning originalism provided for the best institutional structure for the protection of such rights, then one might believe that a naturalrights version of extratextual fundamental law is consistent with originalism.

The word "originalism" is a neologism, coined by Paul Brest to describe a constitutional theory that he opposed. ${ }^{68}$ Some originalists may believe that the spirit of originalism is fundamentally inconsistent with the notion of freestanding extratextual fundamental law, and hence freestanding extratextual fundamental law should not be called "originalist." Other originalists may insist, with equal fervor, that natural-rights extratextual fundamental law is at the core of the original meaning of the Constitution. Once we recognize that "originalism" is a stipulated theory term, it becomes clear that there is no truth of the matter in this debate. The best we can do is to be clear about the meaning of our stipulated theoretical language. My own view is that any constitutional theory that affirms the fixation thesis and the constraint principle is properly called "originalist," given the patterns of self-identification of contemporary constitutional theorists who endorse originalism. The disputes about freestanding unenumerated constitutional rights reflect dispute among originalists about the correct formulation of the constraint principle.

\section{G. Enactment Arguments}

One of the most interesting contributions made by Akhil Amar in America's Unwritten Constitution is his proposal for a distinctive form of contextual enrichment. In this section, we shall investigate Amar's proposal from the perspective of public meaning originalism. Should originalists embrace Amarian enactment arguments?

67. This can easily be demonstrated. Add an extratextual fundamental law clause to the constitution. The new provision does not contradict or invalidate any of the communicative content of the constitutional text. It follows that the negation of the imaginary provision is not implied by the communicative content of the actual text.

68. See Solum, supra note 17, at 13 . 
We can begin our investigation with an explication of Amar's statement of his argument. Amar focuses on the ratification process as the basis for constitutional implicature. He calls this kind of argument from extratextual sources "argument from enactment" or "enactment argument." 69 Here is Amar's description:

In the fateful year following the unveiling of the Philadelphia delegates' proposed Constitution in September 1787, specially elected ratifying conventions across the continent enacted the proposal into law, much as the houses of an ordinary legislature might enact a statute. The specific enacting procedures and protocols that brought forth the Constitution are rich with meaning. They invite interpretation.

The sort of interpretation I have in mind here is not interpretation of what the Constitution says as a text, explicitly or implicitly. Rather, it is the interpretation of how the Constitution became law. $^{70}$

In particular, Amar argues that the enactment both provides an independent ground for the freedom of speech and provides that right with content. His explanation provides further clarity:

The claim is not that free speech generally prevailed on the ground in postcolonial America. ... Rather, the special twist is that the very act of constitutional ordainment itself occurred in and through a regime of boisterous, virtually uncensored free speech. In this respect, the argument from enactment history functions like a standard textual argument, which also focuses tightly on the Constitution itself. But the enactment approach understands the Preamble's self-reference to "this Constitution" as a deed as well as a text - a doing, an ordainment, a constituting, a performative utterance. In short, an enactment, reflected in the text itself: "We the People ... do ordain and establish this Constitution."71

And he provides another gloss in an adjacent passage:

To put the point a slightly different way, an enactment argument can perhaps be seen as a textual argument of sorts - an interpretation of the tiny but powerful workhouse word "do" in the Preamble. The argument from enactment prompts us to understand what was in fact done by the people in the very process of ordaining and establishing the Constitution. And what was done... was a remarkable embodiment of free speech, speech that was inextricably intertwined with the very deed of ordainment itself. ${ }^{72}$

And in another passage, Amar identifies yet another characteristic of enactment arguments:

Enactment arguments also share one of the great strengths of various classical arguments derived from the Constitution's general

69. AMAR, supra note 5, at 54

70. Id. at 51 .

71. Id. at 55

72. Id. 
structure: a focus on the Constitution as a whole rather than on some small clause or part. Whereas many standard textual arguments are small-bore and clause-bound, enactment arguments are panoramic, drawing out attention to how the entire Constitution came into being. In this sense, an enactment argument is the ultimate structural argument, with a historical twist. ${ }^{73}$

Finally, he integrates the ideas in the three above-quoted passage as follows: "Howsoever we classify enactment arguments - whether we view them as historical, or textual, or structural-we need to see that the written Constitution and the unwritten Constitution cohere to form a single system." 74

The final passage sheds light on the preceding three, suggesting that Amar sees three possible understandings of enactment arguments, we can label them as follows (1) "the historical understanding," (2) "the textual understanding," and (3) "the structural understanding."

These passages are highly suggestive, but they do not make the theoretical structure of enactment arguments transparent. How precisely does the enactment argument work? In the case of freedom of speech, the general idea seems to be that the enactment process displayed a conception of the freedom of speech, and therefore the freedom of speech is (or should be) part of the legal content of constitutional doctrine. Stated in this way, the argument is enthymematic: the missing premise would provide a warrant for moving from the fact that ratification of the Constitution was conducted under conditions of free speech to the conclusion that those conditions (or the conception that best fits them) have legal force.

What is the missing premise? Consider first the textualist understanding of the enactment argument. Viewed as a textual argument focused on the word "do" in the Preamble of the Constitution, the enactment argument does not go through. Amar correctly observes that the Preamble uses the word "do" in "We the People ... do ordain and establish this Constitution" and that it plays a performative function. Implicitly, Amar is referring to speech-act theory, elegantly introduced by J.L. Austin's classic, How to Do Things with Words. ${ }^{75}$ Austin's key insight is that utterances have what is called "illocutionary force" - they can make promises, issue commands, reject an offer, and so forth. ${ }^{76}$ The Preamble, when read in conjunction with the ratification provisions of Article VII, ${ }^{77}$ may constitute an illocutionary act: upon ratification, "We the People" perform an action, ordaining and establishing this Constitution. The in-

73. Id. at $55-56$.

74. Id. at 56

75. J.L. Austin, How to Do Things with Words (J. O. Urmson \& Marina Sbisà eds., 2 d ed. 1975).

76. Id. at 100 .

77. U.S. CONST. art. VII ("The Ratification of the Conventions of nine States, shall be sufficient for the Establishment of this Constitution between the States so ratifying the Same."). 
dexical "this" (which appears in both the Preamble and Article VII) makes it clear that ratification ordains and establishes the Constitution contained in the text in which the Preamble and Article VII appear-the text contained in the document that was produced at the Philadelphia Convention and that is now displayed in the National Archives.

Is there a textualist argument for a particular conception of the freedom of speech based on the meaning of the word "do" or the speech act of ordaining and establishing the Constitution of 1789? Of course, the contribution of the word "do" to the semantic content of the Constitution does not include a conception of the freedom of speech-and Amar could not be charitably interpreted to make a claim that it does. "Do" does make a contribution to the semantic content of the Constitution: "do" connects the illocutionary action of ordaining and establishing to an agent, "We the People." But this semantic contribution does not include a conception of the freedom of speech: the semantic content of the word "do" is both too sparse and too far in conceptual space from freedom of speech to play this role.

What about the speech act of ordaining and establishing the Constitution of 1789? A full account of the illocutionary force of this act would be complex and is outside the scope of this Essay. Nonetheless, we can reach some obvious conclusions about the content of the illocutionary force. The text of both the Preamble and Article VII clearly refer to "this Constitution." As Christopher Green has argued, this use of the indexical strongly suggests that it is the text of the Constitution of 1789 that was ordained and established. ${ }^{79}$ If Green is correct, then the textualist understanding of the enactment argument does not support the freedom of speech - unless the freedom of speech can be located in the text itself. We can bracket the question of whether there is a freedom of speech in the communicative content of the text of the Constitution of 1789. The crucial point is that the communicative content of the text is not the entire ratification process. The text is one thing; the ratification process is another. The text has semantic content; the conception of freedom of speech displayed by the ratification process does not have semantic content, although the process can be described in language that does have such content.

One might argue that the Preamble does ordain and establish Article VII, but Article VII itself does not include a conception of the freedom of speech. I will develop the argument in full, but it seems clear that the freedom of speech is not part of the semantic content of "The Ratification of the Conventions of nine States, shall be sufficient for the Establishment of this Constitution between the States so ratifying the Same." ${ }^{80}$ One might try to argue that a conception of the freedom of speech is

78. See generally Christopher R. Green, "This Constitution": Constitutional Indexicals as a Basis for Textualist Semi-Originalism, 84 Notre DAME L. Rev. 1607 (2009) (using indexicals to argue the meaning of the Constitution was fixed at the Founding).

79. Id. at 1660

80. U.S. CONST. art VII. 
built into notion of a "convention" or "ratification," but this proposal seems unlikely to succeed. One way to see this is to imagine a variation of Article VII that disclaimed such an effect: "The Ratification of the Conventions of nine States, shall be sufficient for the Establishment of this Constitution between the States so ratifying the Same. The legislature of each state shall provide such rules regarding the deliberations of such conventions as it deems fit." The revised version of Article VII is not nonsensical, as it would be if the semantic content of "convention" included the freedom of speech.

Because Amar's explicit statement of the textualist understanding of the enactment argument is very brief, it is possible that Amar might attempt to connect the word "do" to a conception of the freedom of speech in some other way. The discussion in the preceding paragraph shows that such a conception is not to be found in the semantic content of the Preamble or the illocutionary force of the speech act of ordaining and establishing the Constitution of 1789.

Amar offers two other understandings of the idea of an enactment argument, which he calls "structural" and "historical." explication is brief and fragmentary, but what he does say suggests that both of these understandings are contextual enrichment arguments. As we have already seen, the structure of the Constitution forms an important part of the context of individual clauses. Modest holism, which embraces the idea of the hermeneutic circle and intratextualism, identifies the distinctive modalities of structural arguments. ${ }^{82}$

Can enactment arguments be understood as structural in the sense specified by modest holism? Here, Amar's move is to argue that the ratification process is part of the Constitution. What does that claim mean? Amar cannot be charitably construed as claiming that the ratification process is part of the constitutional text. To begin, the ratification process is not a text, although it includes texts. The various writings and utterances that are part of the process are not part of the constitutional text. Is there an alternative interpretation of Amar's claim that the ratification process is part of the text? The most plausible alternative is contextual. That is, we can understand Amar's structural argument as claiming that the ratification process is part of the publicly available context of constitutional communication, and hence that ratification can be a source of contextual enrichment.

This interpretation of the structural understanding of the enactment argument can be applied to the historical understanding as well. The ratification process is part of the historical context of the constitutional text. From an originalist perspective, history is relevant for two reasons: (1) it provides linguistic facts relevant to the determination of semantic content, and (2) some historical facts are part of the publicly available context. The historical understanding of the enactment argument can be re-

81. See AMAR, supra note 5, at 56

82. See supra Part IV.D. 
constructed as an argument about publicly available context. Of course, not all of the ratification process was available to the American people in general. Some parts of the process were behind the scenes and not publicly accessible at all. Some events occurred in meetings that were only accessible to the participants and those to whom they reported in oral conversations or private letters. But some of the events surrounding ratification were widely reported and hence publicly available. Let us assume that the "regime of boisterous, virtually uncensored free speech" 83 reported by Amar satisfies the conditions for inclusion in the publicly available context of constitutional utterance.

We can now summarize our progress in unpacking Amar's enactment argument. Although the argument might be interpreted as making a claim about the semantic content of the Constitution or about the content of the illocutionary force of the speech act of ordaining and establishing the Constitution of 1789, these interpretations are neither charitable to Amar nor plausible. The best interpretation of the textual, structural, and historical understandings of the enactment argument is contextual. Parts of the ratification process are included in the publicly available context of constitutional communication, and hence are eligible sources for contextual enrichment.

Understood in this way, Amar's enactment argument remains enthymematic. For the argument to be complete, Amar would need to spell out the specific mechanism by which public awareness of the ratification process created communicative content including the freedom of speech. One can imagine various ways the argument might go. Amar might argue for a constitutional implicature: robust freedom of speech during the ratification process implicates an unstated principle of freedom of speech that should guide construction of the power grants in the first three Articles of the constitutional text. Or Amar might make an argument that the ratification process implicitly precisifies vague or open-textured provisions; perhaps the vague and possibly ambiguous word "proper" in the Necessary and Proper Clause. There may be other possibilities as well. Because Amar's statement of the argument is incomplete, it is difficult to assess its validity from an originalist perspective.

The question addressed here is whether originalists can accept enactment arguments as a type-whatever the merits of the particular argument tokens advanced by Amar in America's Unwritten Constitution. If the enactment argument is understood as a form of contextual enrichment, then originalists can embrace it; contextual enrichment is a paradigmatic form of originalist argument, precisely because context is one of the sources of original meaning (understood as communicative content). Understood in this way, Amar's contribution is identification of a particular type of contextual enrichment-based on the characteristics of the process of ratification. Originalists should have no quarrel with the

83. AMAR, supra note 5 , at 55 
type-although Amar's particular arguments (e.g., his free speech argument) could be contested on their merits (once they were fully specified).

\section{H. Nonconstitutional Texts}

Should originalists embrace arguments that use nonconstitutional texts as sources of constitutional doctrine? For example, should originalists embrace arguments that derive the legal content of constitutional doctrine from the Declaration of Independence, the Treaty of York, Blackstone's Commentaries, or the Federalist Papers? Various versions of these questions have been the subject of vigorous debate. For example, Lee Strang has argued that the Declaration of Independence should not be viewed as an independent source of constitutional norms ${ }^{84}$ but others, such as Scott Gerber, have argued that the Declaration should play a robust role. ${ }^{85}$ For the purposes of this discussion, a "nonconstitutional text" is any text that is not part of the United States Constitutionthe Constitution of 1789 plus all of the subsequent amendments; roughly, the version of the Constitution in the United States Code.

Akhil Amar has argued generally for a robust role for extraconstitutional texts, which he treats as part of America's "symbolic constitution":

America's symbolic constitution surely includes (but is not limited to) the Declaration of Independence, Publius's The Federalist, the Northwest Ordinance, Lincoln's Gettysburg Address, the Warren Court's opinion in Brown v. Board, and Dr. King's "I Have a Dream speech."

These works set forth background principles that powerfully inform American constitutional interpretation. Wherever the written Constitution is fairly susceptible to different interpretations, interpreters should hesitate, and do in fact hesitate, to embrace any reading that would violate the clear letter and spirit of these other canonical texts. In short, these texts are constitutional in the sense that they are constitutive-adherence to these texts helps constitute Americans as a distinct people among all the peoples of the earth. ${ }^{86}$

There is much going on in this passage; examining Amar's case for nonconstitutional texts as sources of constitutional law can help us to untangle the various roles such texts might play.

Once again, our question is how nonconstitutional texts should be viewed from an originalist perspective. We can begin with an easy case for public-meaning originalists. Some nonconstitutional texts are clearly part of the publicly available context of constitutional communication. Such documents include The Federalist Papers and the Declaration of Independence. Because they are part of the publicly available context,

84. Lee J. Strang, Originalism, the Declaration of Independence, and the Constitution: A Unique Role in Constitutional Interpretation?, 111 PENN ST. L. REV. 413, 414 (2006).

85. Scott Douglas Gerber, To Secure These Rights: The Declaration of INDEPENDENCE AND CONSTITUTIONAL INTERPRETATION 3 (1995).

86. AMAR, supra note 5, at 247. 
they can play a role in arguments for contextual enrichment of the semantic content of the constitutional text. Such enrichments might include the clarification of ambiguity, constitutional implicatures, or arguments about implicit content.

Originalists should embrace another role for nonconstitutional texts. The semantic component of original meaning is fixed by linguistic facts as they stood at the time each provision of the Constitution was framed and ratified. Linguistic facts are established or known on the basis of evidence. In the case of very recent amendments, there may be audio recordings that could be the source of evidence about relevant linguistic facts, but for the Constitution of 1789 and most of the amendments, the relevant linguistic evidence will be provided by nonconstitutional texts-including publicly available documents like The Federalist Papers, but also including nonpublic documents like diaries, private letters, and even the nonpublic records of the Philadelphia Convention.

There is a third role for nonconstitutional texts that some originalists may embrace. Nonconstitutional texts might serve as evidence of what Philip Bobbitt calls "ethos," the shared values of the American people. ${ }^{87}$ Some constitutional theorists may believe that such values trump the communicative content of the constitutional text, but the constraint principle commits originalists to the view that ethos can play only a supplementary role. Deploying the terminology of the interpretationconstruction distinction, ethos (as evidenced by canonical nonconstitutional texts) could guide constitutional actors in the construction zonebut would have no direct relevance to constitutional interpretation. This view is close to that expressed by Amar, who writes, "True, these special texts are not on the same legal level as the written Constitution itself. Where the terse text is clear, it trumps. But often the written Constitution is not crystal clear." 88 To be clear, different originalists have different views about constitutional construction and the constraint principle: some originalists may reject the idea that substantive values can play a role in the construction zone; for example, originalists might adopt a Thayerian rule of construction, deferring to elected officials when the communicative content of the constitutional text is vague or irreducibly ambiguous. ${ }^{89}$

In sum, originalists can embrace three roles for nonconstitutional texts: (1) if the text is part of the publicly available context of constitutional communication, the text can serve as the part of the basis for contextual enrichment; (2) if the text is contemporaneous with the framing and ratifying of a particular provision, the text can provide evidence of linguistic facts that determine semantic content; and (3) if the text pro-

87. BOBBITT, supra note 54, at $12-13$.

88. AMAR, supra note 5, at 247-48.

89. JAmes Bradley Thayer, The ORIGin AND SCOPE OF THE AMERICAN Doctrine OF Constitutional Law 25-26 (Boston, Little Brown \& Co. 1893). 
vides evidence of norms relevant to constitutional construction, the text may guide the development of constitutional doctrine in the construction zone.

There is a fourth role for nonconstitutional texts. Some of these texts, such as the Declaration of Independence or the Treaty of Paris, could arguably be part of the Constitution. The conventional wisdom in constitutional theory is that the text is limited to the Constitution of 1789 and the canonical set of amendments recognized in the United States Code. Analogizing with the Bible, we can label the disputed texts "constitutional apocrypha." 90 How should originalists view constitutional apocrypha? Originalists, like other constitutional theorists, will need to answer the question of canonicity: are the apocrypha properly viewed as part of the constitutional canon? The question whether a particular text in the aporcypha should be moved into the canon is complex, and outside the scope of this essay. My guess is that very few originalists will accept expansion of the constitutional canon. If a particular text were moved into the canon, then originalists will insist that the (once apocryphal, now canonical) text be interpreted in light of the fixation thesis: the meaning of the Declaration of Independence or the Treaty of Paris was fixed at the time these documents were written. And if they are canonical, then the constraint principle would apply: constitutional doctrine should (at a minimum) be consistent with their communicative content.

\section{Precedent}

What role should precedent (or judicial opinion) play in constitutional practice?

In particular, how should originalism treat precedent? This is a large topic on which much has been written. ${ }^{91}$ One useful way into the problem is via the interpretation-construction distinction. Interpretation seeks the linguistic meaning of the text. Construction determines the legal content of constitutional doctrine and the effect of that content in particular cases.

What about precedent and constitutional interpretation? Originalists are committed to the fixation thesis: the communicative content of the constitutional text is fixed at the time each provision is framed and ratified. Public-meaning originalists believe that the communicative content is a function of the conventional semantic meaning of the text and

90. See The New OXford Annotated Apocrypha: New Revised Standard Version (Michael D. Coogan, et al. eds., 2010).

91. Originalist writing on this topic includes Randy E. Barnett, Trumping Precedent with Original Meaning: Not as Radical as it Sounds, 22 Const. COMMENT. 257 (2005); Kurt T. Lash, Originalism, Popular Sovereignty, and Reverse Stare Decisis, 93 VA. L. REV. 1437 (2007); John O. McGinnis \& Michael B. Rappaport, Reconciling Originalism and Precedent, 103 Nw. U. L. REV. 803 (2009); Lawrence B. Solum, The Supreme Court in Bondage: Constitutional Stare Decisis, Legal Formalism, and the Future of Unenumerated Rights, 9 U. PA. J. Const. L. 155, 159 (2006); Lee J. Strang, An Originalist Theory of Precedent: Originalism, Nonoriginalist Precedent, and the Common Good, 36 N.M. L. REV. 419 (2006). 
contextual enrichment (by the publicly available context of constitutional communication). On the surface, these commitments might lead to the conclusion that precedent should have no effect on constitutional interpretation. If a constitutional precedent correctly identifies and applies original meaning, then it is redundant. And if a constitutional precedent departs from original meaning, then the constraint principle would seem to require originalists to disregard the precedent.

Akhil Amar has concisely expressed the originalist worry about precedent that departs from original meaning:

If the justices generally felt free (or obliged!) to follow clearly erroneous case law concerning the core meaning of the Constitution, then the foundational document might ultimately be wholly eclipsed. Rather than simply filling the document's gaps, judicial doctrine would erase its outlines. If the written Constitution indeed contemplated this odd result, one would expect to see a rather clear statement to that effect: "This Constitution may be wholly superseded by conceded judicial misinterpretation; all branches are oathbound to follow these misinterpretations." But the Constitution says nothing of the sort. On the contrary, it explicitly and selfreferentially obliges all officials to swear oaths to itself, not to conceded misinterpretations of it. ${ }^{92}$

But this simple picture is misleading. A regime of constitutional interpretation must answer at least two distinct questions. The first question addresses the substantive content of constitutional meaning; publicmeaning originalism has a distinctive answer to this question. The second question concerns the institutional structure by which constitutional meaning is determined and implemented.

A fully developed version of originalist constitutional practice must address the second question - specifying which institutions are responsible for determining original meaning and how these interactions will structure the activity of constitutional interpretation. One institutional possibility would be polycentric constitutional interpretation: each individual official could make independent judgments about constitutional meaning. The most extreme version of a polycentric regime would be radically different than the status quo. For example, there would be neither horizontal nor vertical stare decisis: each judge would make independent judgments about the meaning of the Constitution. In a purely polycentric regime, executive and legislative officials would have similar interpretive authority - in the extreme case, disregarding coercive judicial orders that were inconsistent with their individual constitutional judgments.

But polycentric constitutional interpretation is not the only possible originalist regime. For example, originalists might adopt the status quo practice that gives the United States Supreme Court the final word on questions of federal constitutional law-unless the political question doc-

92. AMAR, supra note 5, at 237. 
trine applies. This practice would require lower court judges and other officials to defer to the Court on questions of constitutional interpretation-even if they believed that the Court had erred. Similarly, the current Supreme Court could defer to its prior self; adopting the doctrine of horizontal stare decisis to structure constitutional interpretation. So long as this institutional structure is consistent with the original meaning of the Constitution, this option is available to originalists. Whether it is the best option depends on a variety of complex institutional questionseffects on stability, efficacy in maintaining original meaning, and so forth.

Precedent might also play a role in constitutional construction. For originalists who embrace the construction zone, nonoriginalist considerations inevitably play a role in constitutional practice when the communicative content of the constitutional text is vague or irreducibly ambiguous. In the construction zone, both vertical and horizontal stare decisis could structure constitutional doctrine-by definition the construction zone is the space in which the original meaning of the Constitution underdetermines the legal content of constitutional doctrine.

It should be uncontroversial that originalists can embrace an institutional role for precedent-so long as that role is consistent with the constraint principle. There is, however, a question about the proper role of precedent that is bound to be controversial. Can originalists accept precedents that are both (1) contrary to original meaning, and (2) decided on the basis of nonoriginalist concerns? Although some originalists have argued that Brown v. Board can be justified on originalist grounds, ${ }^{93}$ suppose that Brown is inconsistent with original meaning and that the opinion in Brown cannot be fairly read as a good-faith attempt to reach a decision consistent with original meaning. Under these circumstances, would originalists be compelled to argue that Brown should be reversed? Or consider the New Deal-era precedents that expanded national legislative power and provided the constitutional foundations for the exercise of legislative, executive, and judicial powers by administrative agencies. ${ }^{94}$ Assuming that these decisions are inconsistent with original meaning and that their reasoning cannot be characterized as a good-faith attempt to respect original meaning, must originalists argue that they should be overruled?

Justice Scalia has argued for "faint-hearted originalism"-which reconciles originalism with nonoriginalist precedents on pragmatic grounds. ${ }^{95}$ Randy Barnett has forcefully criticized Scalia's argument. ${ }^{96}$ This theoretical disagreement can be characterized in terms of the constraint principle. Originalists differ about the precise contours of the constraint principle. Some, like Scalia, adopt versions of the constraint

93. See Michael W. McConnell, The Originalist Case for Brown v. Board of Education, 19 HARV. J. L. \& PUB. POL'Y 457, 458 (1996).

94. See. e.g., Wickard v. Filburn, 317 U.S. 111 (1942).

95. Antonin Scalia, Originalism: The Lesser Evil, 57 U. CIN. L. REV. 849, 862 (1989).

96. Randy E. Barnett, Scalia's Infidelity: A Critique of "Faint-Hearted" Originalism, 75 U. L. REV. 7, 24 (2006). 
principle with defeasibility conditions that are broad in scope. Others, like Barnett, believe in relatively narrow defeasibility conditionsalthough every originalist is likely to accept that original meaning must give way in some cases: the Constitution is not a suicide pact. ${ }^{97}$ When defeasibility conditions come into play, the resulting doctrines are constitutional constructions: legal content of constitutional doctrine that is inconsistent with the communicative content of the constitutional text. The question whether originalists should adopt broad or narrow defeasibility conditions is a complex one: the answer depends on the underlying justifications for originalism, broader issues in political philosophy, and empirical questions about institutional design. These topics are important, but they cannot be resolved on this occasion and are likely to be the subject of ongoing dispute among originalists.

\section{J. Historical Practice}

The final category of extratextual sources of constitutional law to be examined here is historical practice by the political branches. How should originalists treat constitutional arguments based on the institutional practices of the President and Congress? Should such practices have special authority if they were close in time to the adoption of a particular constitutional provision? For example, should the actions of the first Congress and George Washington have special authority with respect to interpretation and construction of the Constitution of 1789 ? These questions can be made more precise by distinguishing the role of historical practice in interpretation and construction.

Consider first the role of historical practice in constitutional interpretation. In the sense stipulated by the interpretation-construction distinction, interpretation aims to recover the communicative content of the constitutional text. Direct evidence of communicative content comes from two sources: (1) evidence of linguistic facts that establish conventional semantic meaning, syntax, and grammar, and (2) historical evidence of the publicly available context of constitutional communication. Post-ratification practice by the executive and legislative branches do not provide direct evidence. Such practices are not linguistic facts. And post-ratification practice cannot be part of the publicly available context of communication - because such practices occur after the communicative acts (framing and ratification) have occurred.

Nonetheless, historical practice can provide indirect evidence of original meaning. Suppose that known linguistic facts underdetermine the meaning of a constitutional provision. A typical case of such underdeterminacy might be ambiguity. A word or phrase in the Constitution could have two (or more) semantic meanings. The first Congress legislates in a way that is consistent with one of the alternatives, but not the other. One might infer that Congress's action provides evidence in favor

97. Terminiello v. City of Chicago, 337 U.S. 1, 37 (1949) (Jackson, J., dissenting). 
of the interpretation that is consistent with the constitutionality of the legislation. Of course, this evidence is not decisive-after all Congress (even the first Congress with members who attended the Philadelphia Convention and various ratifying conventions) could be mistaken-or Congress could have failed to recognize the issue or deliberately violated the Constitution. Nonetheless, early historical practice provides evidence relevant to the resolution of the ambiguity.

How should originalists regard the use of historical practice in constitutional construction? Originalists are committed to the constraint principle. When the meaning of the text is clear and relevant, originalists will adopt a construction that aligns the legal content of constitutional doctrine with the communicative content of the constitutional text. But in the construction zone, there may be more than one constitutional doctrine permitted by a vague or irreducibly ambiguous text. So originalists can accept the use of historical practice to liquidate constitutional meaning in the construction zone. Akhil Amar expresses this idea eloquently, using the phrase "institutional practice" to express the idea we have been considering using the similar phrase "historical practice":

First, institutional practice routinely goes beyond the written Constitution. Second, institutional practice rarely goes against the canonical document. Typically, the foundational text significantly constrains even if it does not exclusively control.

In general, the underspecified text and the more specific institutional practices cohere to form a single system of daily governance in which the practices gloss and clarify the text, inducing interpreters to read the otherwise indeterminate text in a highly determinate way. On a broad set of topics concerning the interactions and internal operations of governmental entities, post-1789 institutional practice thus furnishes a powerful lens through which to read the 1789 blueprint. $^{98}$

Amar expresses himself in a slightly different vocabulary than we have employed. He uses the word "indeterminate" to express the concept we have labeled "underdetermination." Amar doesn't employ the interpretation-construction distinction, but his terms "gloss" and "clarify" are consistent with the distinction between interpretation and construction.

Originalists can embrace a role for historical practice in constitutional construction. Should they do so? Once again, this is a complex question and different originalists may approach it differently. Originalists whose normative concerns focus on the rule of law and judicial constraint may welcome historical practice arguments - as they provide a basis for settling constitutional questions. Settlement serves the rule of law values of stability, certainty, and predictability. Settlement also serves the function of constraining judges, by providing a basis for decision that does not require judges to make first-order normative judgments about the political morality of the settled institutional arrangements. Other

98. AMAR, supra note 5, at 335. 
originalists may argue that historical practices should play a modest role because they envision a greater role for normative concerns in the construction zone. And yet other originalists may believe that judges should generally defer to the political branches in the construction zone; these originalists may believe that the normative force of historical practice should be assessed by the political branches and hence that Congress or the President may depart from such practices without judicial interference.

\section{A Case Study: CAN Vice Presidents Preside at Their OWN TRIAL BY THE SENATE?}

In America's Unwritten Constitution, Akhil Amar explores a hypothetical case that raises a series of problems for originalism's commitment to the constitutional text. He posits an impeachment and trial of Andrew Johnson for high crimes and misdemeanors in 1865, when Johnson was Vice President of the United States. Could Johnson have insisted that he should serve as the President of the Senate and hence preside at his own trial? Amar suggests that this result is required by the written Constitution, but that it is clear that the correct constitutional result would disqualify the President of the Senate from serving in this role. ${ }^{99}$ If Amar is correct about the implications of the text and the proper rule of constitutional law, his hypothetical poses a particular problem for originalists. Originalists are committed to the constraint principle. If that principle requires that the Vice President be permitted to serve as presiding officer in his own trial, but that outcome is clearly unconstitutional, then the constraint principle is wrong. We might then draw the conclusion that the constraint principle must be modified to take into account an "unwritten constitution" - or to use our preferred terminology, that extratextual sources should, in some cases, give rise to constitutional doctrines that are inconsistent with the communicative content of the constitutional text.

Section Three of Article One of the Constitution provides:

The Vice President of the United States shall be President of the Senate, but shall have no Vote, unless they be equally divided.

The Senate shall chuse their other Officers, and also a President pro tempore, in the Absence of the Vice President, or when he shall exercise the Office of President of the United States.

The Senate shall have the sole Power to try all Impeachments. When sitting for that Purpose, they shall be on Oath or Affirmation. When the President of the United States is tried, the Chief Justice shall preside: And no Person shall be convicted without the Concurrence of two thirds of the Members present. ${ }^{100}$

Section Five of Article One provides:

99. Id. at 6-19.

100. U.S. CONST. art. I, $\S 3$, cl. 6 . 
Each House may determine the Rules of its Proceedings, punish its Members for disorderly Behaviour, and, with the Concurrence of two thirds, expel a Member. ${ }^{101}$

The conjunction of the semantic content of these three provisions seems to suggest that the Vice President should preside in the case of a trial by the Senate upon his own impeachment by the House of Representatives. The Vice President is the President of the Senate. The Senate has the power to try impeachments. The Vice President is not disqualified from serving as President of the Senate during a trial for impeachment. Therefore, the Vice President is constitutionally entitled to preside at his own trial.

Despite the plausibility of this argument, it not actually the case that the semantic content of Constitution commands this result. First, the Constitution does not specify the rights and duties of the Vice President in his capacity as President of the Senate-with one exception, that he may only vote if the Senate is equally divided. If an impeachment trial resulted in an equally divided vote, the Vice President would not be convicted and hence his tie-breaking vote would not be necessary or of legal effect. It might be argued that the semantic content of the word "President" contains the power to preside at trials for impeachment, but this argument is implausible. The very fact that the Constitution specifies the Vice President's voting rights demonstrates that "President" is an elastic term. The rights and powers of the President of the Senate could be configured in a variety of ways - so long as the presidency contained a sufficient bundle of rights and powers as to be recognizably presidential in character. No one thinks that the "President" of Israel is not a "President" because he does not have the same panoply of powers as does the "President" of the United States. Of course, it is possible that we might discover linguistic facts that specified presiding over "trial in cases of impeachment" as an essential component of the concept of a presidency, but this possibility seems remote and unlikely. ${ }^{102}$

Second, the semantic content of the clause that specifies that the Chief Justice shall preside in the trial of the President does not either state or imply that the Vice President shall preside in all other cases. It is obvious that the clause does not state that the Vice President will preside in impeachment trials of persons other than the President-those words or their equivalent simply do not appear in Section Three of Article One.

101. U.S. CONST. art. I, $\$ 5, \mathrm{cl} .2$.

102. An investigation of the relevant linguistic facts is outside the scope of this essay. A preliminary investigation suggests that one of the meanings of "President" is "an appointed or elected head of any gathering, who presides over meetings and proceedings." OXFORD ENGLISH DICTIONARY president, n.2. If "President" is used in this sense, then "presiding" is clearly one of the Vice President's functions in his role as "President" of the Senate. But this does not settle the matter, as the Vice President would have this role even if there were a rule that qualified the role in the case of his own trial. If such a rule existed, it would surely not entail that the Vice President was no longer the "President" of the Senate, and that fact demonstrates that the semantic content of "President" does not entail the conclusion that the Vice President must preside in all conceivable circumstances. The Constitution itself allows for the selection of a President pro tempore, but does not specify the role. U.S. CONST. art. I., § 3. Moreover, Amar's hypothetical situation has never come to pass in the actual world. 
It should also be obvious that the clause assigning the presiding role at trials of the President does not create an implication to that effect. We need to be careful here. I am using the word "implication" in a stipulated sense-logical implication or entailment. In that sense, there is simply no argument that Section Three (as it stands) logically implies that the Vice President shall preside at his own trial. This can be demonstrated by imagining that Article III stated, "When the Vice President of the United States is tried, the Chief Justice shall preside." The amended version would not contain a logical contradiction, and hence the version without the amended version does not entail that the Vice President shall preside at his own trial. If this result seems counterintuitive to you, this is likely because you recognize some form of contextual enrichment (such as an implicature) to the effect that the Vice President shall preside in all other cases. We shall turn to contextual enrichment in due course. At this stage, we are considering only the semantic content of Section Three and the logical implications of that content.

Third, Section Five of Article One confers upon the Senate the power to make its own rules. If the Senate made a rule that provided that someone other than the Vice President should preside if the Vice President is tried upon impeachment, that would be a rule of the Senate. We have already seen that this rule would not violate the semantic content of Section Three nor any rule logically entailed by the semantic content.

Our conclusion so far is that neither the semantic content of Article Three nor its logical implications compel the conclusion that the Vice President is constitutionally entitled to preside at his own impeachment trial. It might be argued, however, that this conclusion is required by the full communicative content of Article Three after contextual enrichment. The argument would be that although the rights and powers of the President of the Senate are not specified, the text in context suggests this implicitly or through an implicature. The President of the Senate must play some role, and because the Senate is a legislative body, the obvious role is that of presiding officer. This implicit assumption might be confirmed by the assignment of the role of presiding officer to the Chief Justice in cases of trial-the assumption being that the Vice President would be biased in such a case (because the Vice President would succeed the President if he were removed from office). Moreover, Section Three explicitly recognizes the office of President Pro Tempore, who serves as President of the Senate in the absence of the Vice President. Doesn't this specification assume that the role of the Vice President is necessary to the functioning of the Senate because otherwise, this provision would be unnecessary?

There is something to these arguments from contextual enrichment, but they do not establish the necessary conclusion - that the written Constitution confers a right on the Vice President to serve at his own trial for impeachment. Precisely because implicit assumptions and implicatures 
are unstated, their content is frequently underdetermined by the publicly available context of constitutional communication. Suppose that contextual enrichment is sufficient to yield the conclusion that the Vice President ordinarily serves as presiding officer of the Senate-as seems likely. It is not so clear that it also yields the more particular conclusion that the Vice President is entitled to serve as presiding officer in his own trial. Implicit assumptions and implicatures do not work like logical implications - they are frequently underdeterminate and contestable. For this reason, that portion of the communicative content of the Constitution provided by contextual enrichment is frequently vague or irreducibly ambiguous.

Although much more could be said, this seems to be the case with respect to the Vice President's right to preside in his own trial. The communicative content of constitutional text underdetermines the question, opening a construction zone. In this case, the work of constitutional construction would be done by the Senate itself pursuant to its Section Five power to determine its own rules of proceeding. Were the Senate to adopt a rule providing that the President Pro Tempore should preside in the case of an impeachment trial of the Vice President, that rule would reflect a reasonable construction of Section Three.

In the end, the question whether the Vice President may preside at his own trial upon impeachment can be answered plausibly by originalists. This is a case where the text actually says less than a surface inspection reveals. Once we understand the distinction between semantic content and communicative enrichment, the appearance that the Constitution gives the Vice President the right to be judge in his own case dissolves. The Senate's power to adopt rules governing its proceedings would seem to encompass the power to adopt a rule governing the remote possibility that a Vice President would attempt to preside in his own impeachment; such a rule would clearly be within the power of "[e]ach House" to "determine the Rules of its Proceedings."

\section{CONCLUSION: OUR WRITTEN CONSTITUTION}

From an originalist perspective, we have a written constitution. When we engage in constitutional interpretation, the communicative content of the written Constitution is the target of our investigation. The meaning of the written Constitution, however, is not limited to the semantic content of the words and phrases. The full communicative content of the Constitution is a function of text and context-and hence of inferences and implicatures that necessarily involve extratextual sources. When we engage in constitutional construction, originalism endorses a principle of constraint: our constitutional constructions must reflect the communicative content of the text and may not contradict that content. But when the communicative content of the constitutional text underdetermines the content of constitutional doctrine, we are in the construc- 
tion zone. In that zone, extratextual sources necessarily play a role. Sometimes the meaning of the text runs out before we know what to do.

From an originalist perspective, constitutional interpretation and construction necessarily involve extratextual sources, but only when they are deployed in a way that is consistent with fidelity to the original public meaning of the U.S. Constitution. We have a written Constitution; we have constitutional law given shape and content by sources other than the constitutional text. 